NBER WORKING PAPER SERIES

\title{
FROM WORLD BANKER TO WORLD VENTURE CAPITALIST: US EXTERNAL ADJUSTMENT AND THE EXORBITANT PRIVILEGE
}

\author{
Pierre-Olivier Gourinchas \\ Hélène Rey \\ Working Paper 11563 \\ http://www.nber.org/papers/w11563
NATIONAL BUREAU OF ECONOMIC RESEARCH
1050 Massachusetts Avenue
Cambridge, MA 02138
August 2005

Revised version, NBER Conference on G7 current account imbalances: Sustainability and Adjustment. We thank Rich Clarida, Barry Eichengreen, Richard Portes, Cédric Tille, participants at the NBER Conference on G7 Current Account Imbalances and especially our discusssant José de Gregorio for their comments. The views expressed herein are those of the author(s) and do not necessarily reflect the views of the National Bureau of Economic Research.

(C)2005 by Pierre-Olivier Gourinchas and Hélène Rey. All rights reserved. Short sections of text, not to exceed two paragraphs, may be quoted without explicit permission provided that full credit, including ( notice, is given to the source. 
From World Banker to World Venture Capitalist: US External Adjustment and the Exorbitant Privilege Pierre-Olivier Gourinchas and Hélène Rey NBER Working Paper No. 11563

August 2005

JEL No. F3, N1

\section{$\underline{\text { ABSTRACT }}$}

Does the center country of the International Monetary System enjoy an "exorbitant privilege" that significantly weakens its external constraint as has been asserted in some European quarters? Using a newly constructed dataset, we perform a detailed analysis of the historical evolution of US external assets and liabilities at market value since 1952. We find strong evidence of a sizeable excess return of gross assets over gross liabilities. Interestingly, this excess return increased after the collapse of the Bretton Woods fixed exchange rate system. It is mainly due to a "return discount": within each class of assets, the total return (yields and capital gains) that the US has to pay to foreigners is smaller than the total return the US gets on its foreign assets. We also find evidence of a "composition effect": the US tends to borrow short and lend long. As financial globalization accelerated its pace, the US transformed itself from a World Banker into a World Venture Capitalist, investing greater amounts in high yield assets such as equity and FDI. We use these findings to cast some light on the sustainability of the current global imbalances.

Pierre-Olivier Gourinchas

UC Berkeley

693 Evans Hall, \#3880

Economics Department

Berkeley, CA 94720-3880

and NBER

pog@econ.berkeley.edu
Hélène Rey

Department of Economics

Woodrow Wilson School

Princeton University

Fisher Hall

Princeton, NJ 08544

and NBER

hrey@princeton.edu 


\section{Introduction}

This paper takes a fresh look at the historical evolution of the United States external position over the postwar period by carefully constructing the US gross asset and liability positions since 1952 from underlying data and applying appropriate valuations to each components.

The last two decades have been characterized by a sharp increase in international capital flows and in particular by a rising globalization of equity markets. ${ }^{1}$ The broadening of the set of assets internationally traded, the switch to a floating exchange rate regime in 1973 and the larger size of gross asset and liability positions have made it increasingly necessary to incorporate valuation adjustments when computing net foreign asset positions.

The net foreign asset position of a country is nothing but a leveraged portfolio where the country is short in domestic assets and long in foreign assets. Hence, changes in asset prices and exchange rate movements will either tighten or relax the US external constraint. For instance, everything else equal, a depreciation of the dollar generates a capital gain on US foreign asset holdings, which increases the return on its net foreign portfolio. As of December 2004, the BEA reports a US net foreign asset position of $-\$ 2.5$ trillion (or $22 \%$ of GDP), with assets representing $\$ 10$ trillion (85\% of GDP) and liabilities $\$ 12.5$ trillion (107\% of GDP). Almost all US foreign liabilities are in dollars whereas approximately $70 \%$ of U.S. foreign assets are in foreign currencies. Hence a $10 \%$ depreciation of the dollar represents, ceteris paribus, a transfer of around 5.9\% of US GDP from the rest of the world to the US. For comparison, the trade deficit on goods and services was $5.3 \%$ of GDP in 2004. These capital gains can therefore be very large. ${ }^{2}$

This paper revisits a number of historical stylized facts about the US external adjustment in light of the new data that we have put together. ${ }^{3}$ Of particular interest to us is the idea that the US's unique position in the international monetary order allows it to enjoy an 'exorbitant privilege', in the famous words attributed to de Gaulle in $1965 .^{4}$ The specific definition of this exorbitant

\footnotetext{
${ }^{1}$ These phenomena have been documented in particular in Lane and Milesi-Ferretti (2001) and Lane and MilesiFerretti (2004).

${ }^{2}$ See also Tille (2003) and Tille (2004).

${ }^{3}$ We present in the Appendix a line by line description of the database we use in this paper and in Gourinchas and Rey (2005).

${ }^{4}$ In fact, the quote is nowhere to be found in de Gaulle's speeches. It is actually Valéry Giscard d'Estaing, Finance Minister at the time, who spoke of an 'exorbitant privilege' in February 1965. He was then cited by Raymond Aron
} 
privilege has varied over time and with different commentators. For some, it refers to the fact that the US's income balance has remained positive all these years, despite mounting net liabilities. For others -and this was the interpretation favored by the French in the 1960s- the exorbitant privilege referred to the ability of the US to run large direct investment surpluses, ultimately financed by the issuance of dollars held sometimes involuntarily by foreign central banks. This particular interpretation views the US as playing a pivotal role, at the center of the world financial system. In the words of Kindleberger (1965) and Despres, Kindleberger and Salant (1966), the US was the 'Banker of the World', 'lending mostly at long and intermediate terms, and borrowing short' thereby supplying loans and investment funds to foreign enterprises and liquidity to foreign asset holders. Since then, the US has become an increasingly leveraged financial intermediary as world capital markets have become more and more integrated. Hence, a more accurate description of the US in the last decade may be one of the 'Venture Capitalist of the World', issuing short term and fixed income liabilities and investing primarily in equity and direct investment abroad. While the latter interpretation of the 'exorbitant privilege' is, of course, consistent with the former, it is conceptually distinct. The United States' excess return of its external assets over liabilities may come from a 'return effect' (higher returns within each asset class) or from a 'composition effect' (the structure of the balance sheet is asymmetric with more low yielding assets on the liability side). One contribution of this paper is to present a break-up of the 'exorbitant privilege' into these 'return' and 'composition' effects over the whole post war period.

We begin by presenting our estimates of the net foreign asset position of the US between 1952 and 2004 in section 2. In particular, we compare our results to the official numbers. Section 3 provides a first historical measure of the exorbitant privilege by estimating yields and total returns on the net foreign assets of the US between 1952 and now. We show that our data support the notion that the US enjoyed a substantial premium on its gross assets relative to its liabilities and that this premium has been increasing since the collapse of the Bretton Woods fixed exchange rate system.

Section 4 studies the evolution of the composition of gross assets and liabilities and relates it to the role of the US as the world venture capitalist. We find that a non negligible fraction of the in Le Figaro, February 16, 1965 p.1475 of Les articles du Figaro, vol. II (Editions de Fallois). We thank Andrew Moravcsik and Georges-Henri Soutou for this information. 
exorbitant privilege comes from the risk premium that the US enjoys, even though the major part of the exorbitant privilege comes from return differentials between US and foreign assets within each class of assets. Finally, in section 5, we present simple estimates of the amount of depreciation of the US dollar needed to wipe out given amounts of US external debt via both the valuation and trade channels.

\section{Measurement of the US external asset position}

\subsection{The US net foreign asset position reconstructed: 1952-2004}

We first set the stage with a comparison of various estimates of the US net foreign asset position. The methodological details on the construction of our own estimates are provided in appendix A. Briefly, the main drawback of the official series is that they generally measure the US external investment position not at current prices but at historical cost. It is well known, for example, that the current account is measured at historical cost. This implies that the official statistics are inappropriate to study valuation effects. Hence we construct market value estimates of each asset and liability category from 1952 by combining data from the BEA's international investment positions data (after 1980) and data on international transactions from both the BEA and the Flow of Funds. We compute dollar capital gains or losses for each asset category (equity, bonds, FDI, bank loans and trade credit) and apply those valuation adjustments to our international investment position series. We use available Treasury benchmark surveys on external asset and liabilities to form estimates of the currency and country weights in the US investment portfolio. Our constructed series give therefore a quarterly account of US external wealth dynamics at market prices since 1952:1, disaggregated by asset class.

Figure 1 reports three different measures of the US net foreign asset position. We denote by $N F A_{t}$ our constructed net foreign asset position at the end of period $t$. Figure 1 also reports the 'naive' estimate obtained from cumulating current accounts, ${ }^{5}$ as well as the BEA's estimates of the US International Investment Position (IIP) at market value since 1982.

The three series exhibit a striking common trend: the US went from a sizeable creditor position

\footnotetext{
${ }^{5}$ Starting from our estimate of $N F A$ in 1952:1. The current account data are from the NIPA (Table 4.1), since the BoP data only extend back to 1960. There are small differences between the BoP and the NIPA definitions of the current account. These are largely irrelevant for our analysis.
} 


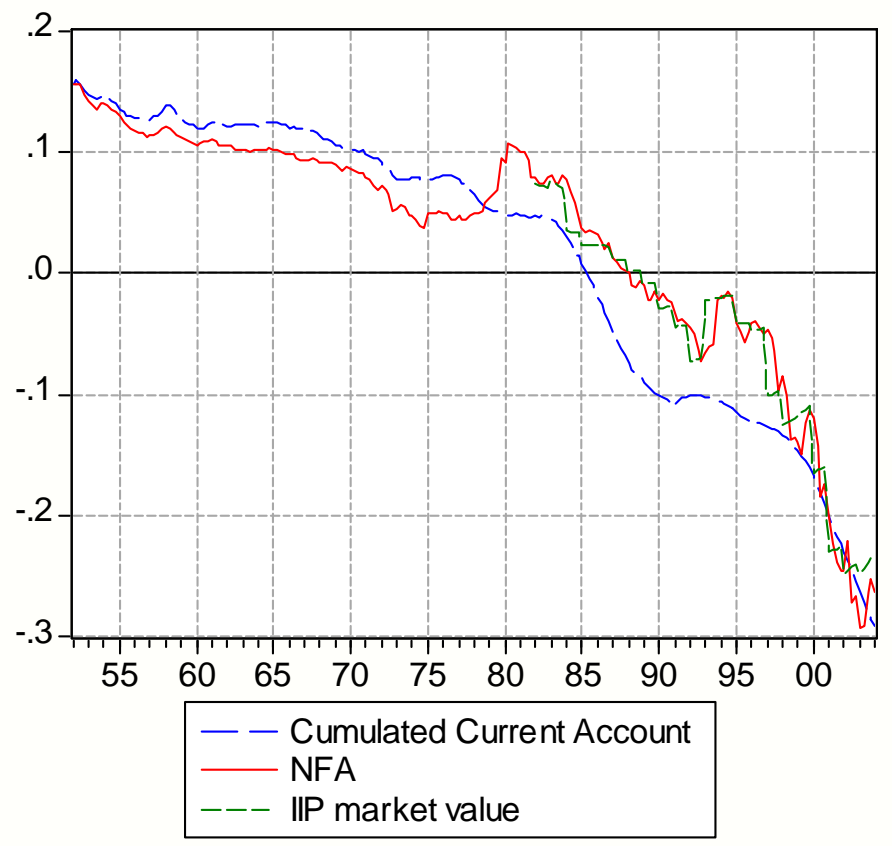

Figure 1: U.S. Net Foreign Assets, relative to GDP. 1952:1 to 2004:1. Source: BEA and Author's Calculations.

in 1952 (15\% of GDP) to a large debtor position (-26\% of GDP) by the end of the period. According to our data, the US became a net debtor around 1988, which is roughly similar to the official data with valuation effects (1989). Our $N F A$ series is also reassuringly close to the BEA's IIP estimates available only after 1982, in spite of a different approach to valuing direct investment positions.

While the general tendency of the three measures is the same, Figure 1 reveals that valuation components have an important influence on the short to medium run dynamics of the US external position. We define the valuation component as the difference between our measure $(N F A)$ and the cumulated current account series $\left(\sum C A\right)$. It reflects exactly the cumulated value of the capital gains and exchange rate adjustments omitted from the current account measure. Figure 2 reports this net valuation component as a share of GDP and highlights a number of interesting facts.

First, during the Bretton Woods period and until 1977, the cumulated current account measure tended to overestimate the NFA position of the US, by up to $4 \%$ of GDP. Since then, valuation effects worked in favor of the US, and reached a peak of 9.4\% percent of GDP in 1994:3. The figure reveals a striking correlation: the valuation component was on average negative while the US was a net creditor, and positive after the US became a net debtor. The startling implication is that 


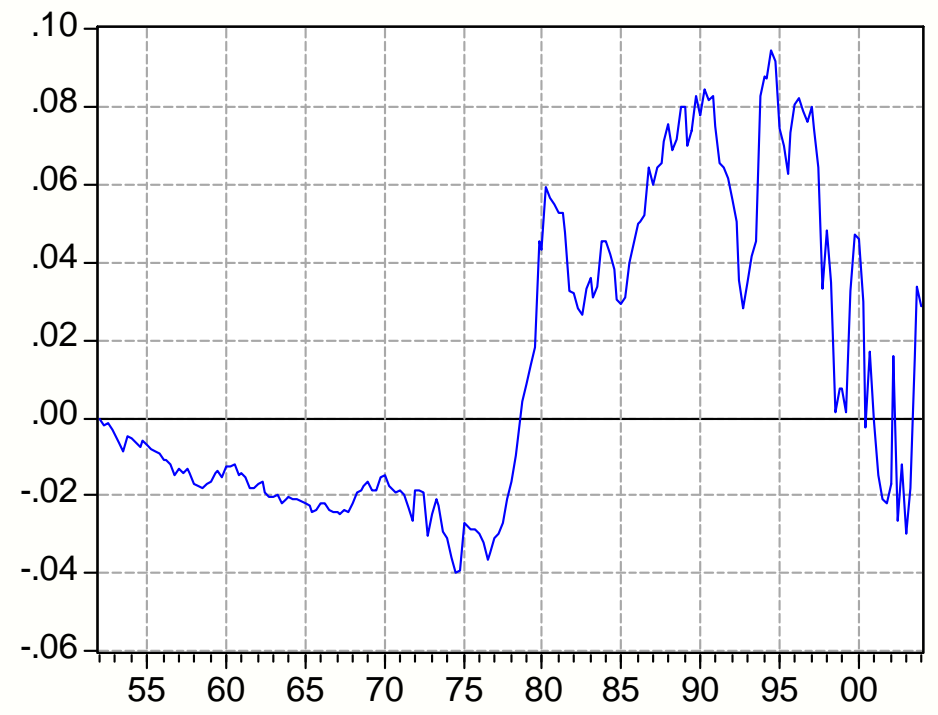

Figure 2: Net Valuation Component (relative to GDP)

over the entire period, and with the exception of a few years, the valuation component worked to stabilize the net foreign asset position of the US and offset current account movements.

Second, the evolution of the valuation component is consistent with the broad evolutions of the US dollar. The period of the dollar depreciation after 1985 as well as the more recent depreciation can be clearly identified on the figure, associated with an increase in the valuation component. Conversely, between 1995 and 2003 the valuation component largely disappeared while the dollar appreciated.

Third, there are a few important exceptions to that pattern. Most dramatically, we observe a dramatic turnaround in the valuation component in 1977-1980. Between 1976:4 and 1980:2, the valuation components shifts from -3.6 percent to 5.9 percent of GDP, a total shift representing about 10\% of GDP. During that period, the returns on US gross foreign assets far exceeded the returns on US gross liabilities. This was in large part due to low returns on US equities. The US stock market dramatically underperformed the foreign stock markets over that period which substantially increased the value of US net foreign assets. ${ }^{6}$

\footnotetext{
${ }^{6}$ During this period, the annual dollar capital gain on the US stock market averaged only $2.2 \%$ while the same return was $31.7 \%$ on the UK stock market and $18.3 \%$ on the Japanese stock market. These two countries accounted for $38 \%$ of US equity assets (see table 6 in appendix B.3).
} 


\subsection{Gross external positions and valuations.}

One additional benefit of reconstructing the net foreign asset position from the underlying disaggregated data is that we can document the time evolution of the gross assets and liabilities separately. Figure 3 and 4 report the 'naive' construction of gross asset and liability positions, starting in 1960

and cumulating the corresponding Balance of Payment flows, together with our estimates. The difference between the two series provides a direct estimate of the valuation component on the underlying gross positions (figure 5 reports the two valuation components side by side)

We observe first that the share of US gross assets in GDP remained stable or even slightly declining between 1952 and 1975 (figure 3). Starting in 1975, it has grown rapidly, reaching 80 percent of GDP in 2000. The share of US gross liabilities in GDP, on the other hand, has increased throughout the postwar period, with a sharp acceleration post-1980 (figure 4).

The valuation component on the gross positions is an order of magnitude larger than on the net positions. It accounts for 45 percent of gross assets and 30 percent of gross liabilities in 2000, and around 35 percent of GDP. The evolution of that component reflects the evolution of asset returns. Both valuation components grew rapidly over time until 2000 (figure 5). Then they declined precipitously as asset prices around the world collapsed.

\section{The Exorbitant Privilege, Part I: Yields and Total Returns}

Now that the stage is set, we begin our analysis of the external balance of the US. We start with the famous observation that the large increase in US net liabilities to the rest of the world has not been accompanied by a commensurate increase in net income payments. It is well-known that the income account has remained positive for the US despite gross liabilities exceeding assets by approximately $34 \%$ in 2004 . In other words, the income generated by the (smaller) US-owned assets abroad is larger than the income paid on the (larger) foreign-owned assets in the US. This observation is sometimes taken as evidence that the US enjoys an 'exorbitant privilege' in the sense that it can borrow at a discount on world financial markets. Figure 6 presents the annual yield on the NFA as a percent of GDP, since 1960. Despite a substantial drop in the mid 1980s, it remained positive throughout the period. 


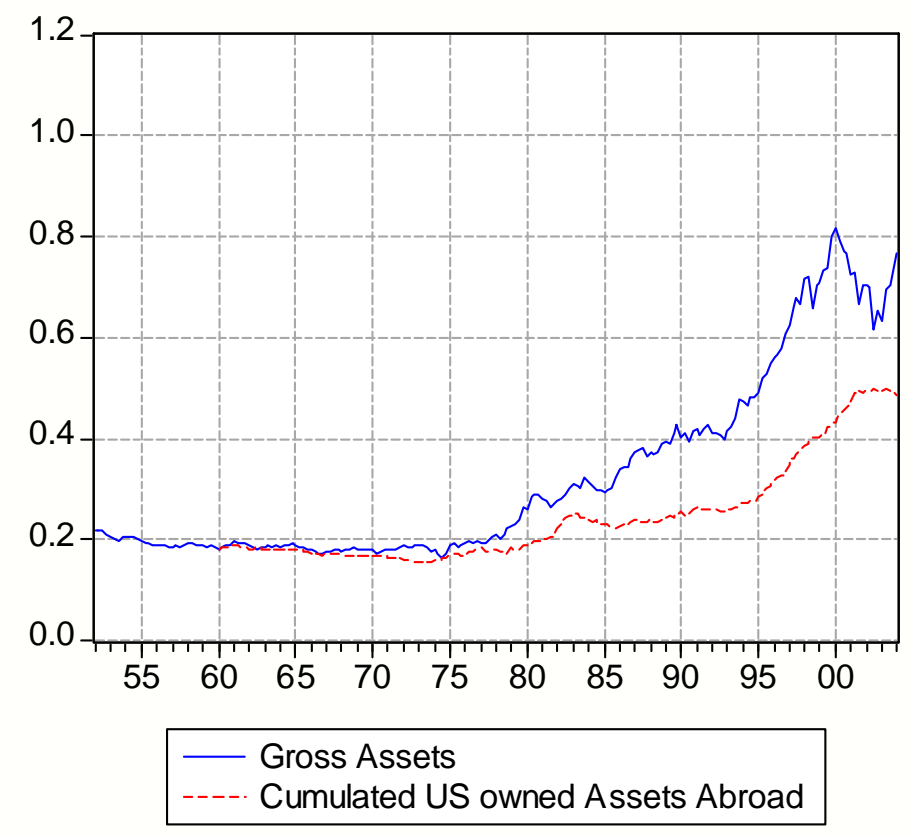

Figure 3: Gross Assets Position and Cumulated US-owned foreign assets (relative to GDP)

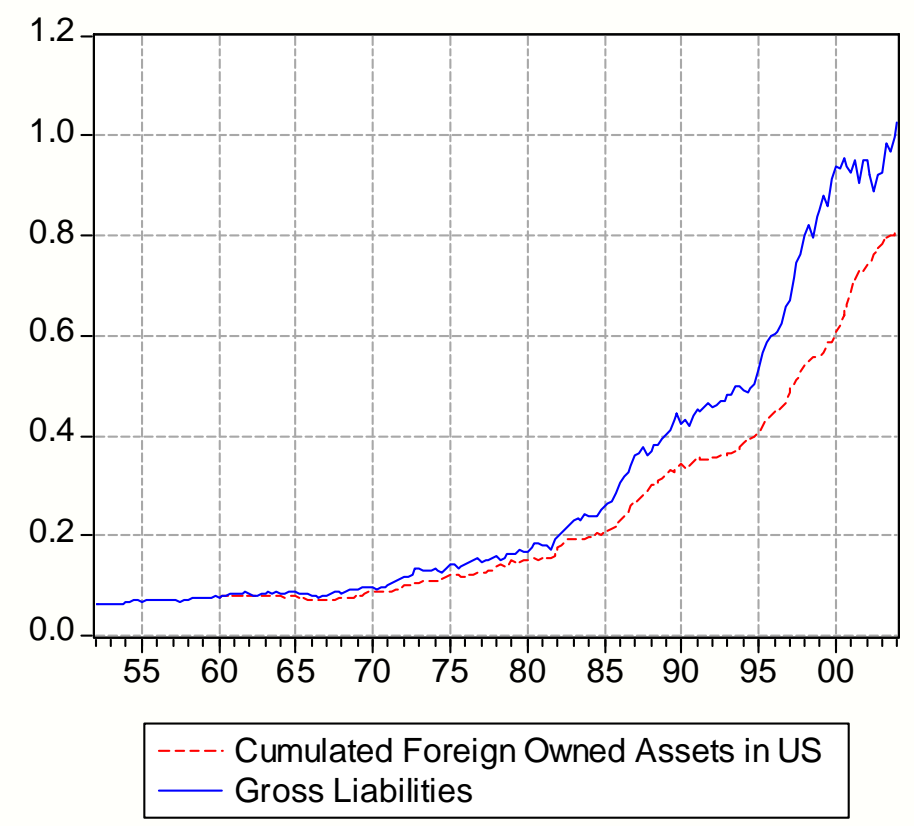

Figure 4: Gross Liability Position and cumulated foreign-owned US assets (relative to GDP). 


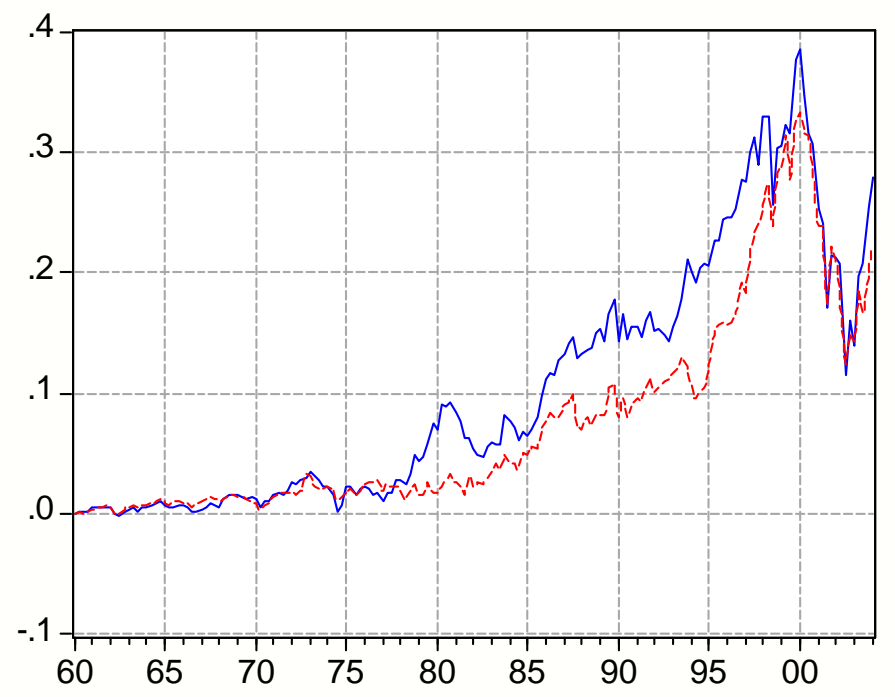

- Gross Foreign Assets ----- Gross Foreign Liabilities

Figure 5: Valuation effects, Gross Foreign Assets and Gross Foreign Liabilities (relative to GDP)

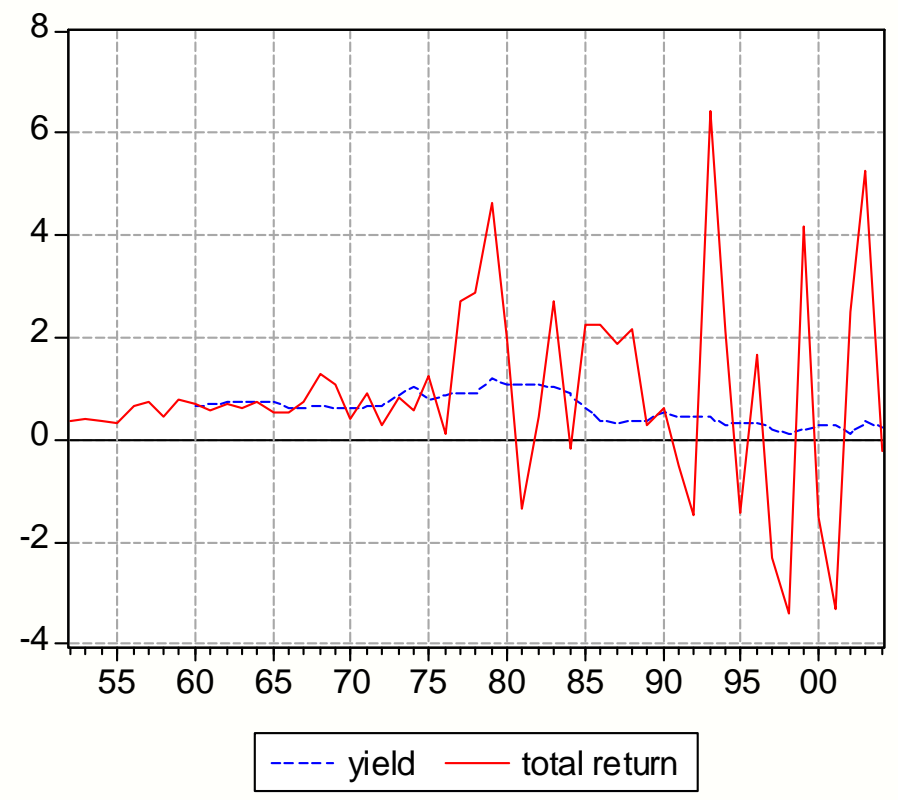

Figure 6: Yield and Total Return on NFA (in percent, annual rate, relative to GDP). Source: US International Transactions (BEA) and author's calculations. 
One should recognize, however, that the yield represents only one component of the total return on US gross external assets and liabilities. The other component is the dollar capital gain or loss due to asset price and currency fluctuations. Figure 6 reports our estimate of the total annual return on the net foreign asset portfolio, as a percent of GDP.

The first striking observation is the volatility of total returns relative to yields, especially after 1975. Total returns fluctuate between -3.4 and 6.4 percent of GDP while the income balance represents between 0.09 and 1.2 percent of GDP (we can see on this figure the large total return between 1976 and 1980 that underlies the turnaround in the valuation component, as well as the effect of the depreciation of the dollar after 1985).

Second, total returns can be substantially negative. The annual return (relative to GDP) was indeed negative in all but two years from 1995 to 2001, a period during which the dollar appreciated substantially.

Third, despite this substantial volatility, the average total return on assets and liabilities is consistent with the evidence on yields. Over the sample period, we find that the annualized average real rate of return on gross liabilities $(3.61 \%)$ is substantially smaller than the annualized average real rate of return on gross assets $(5.72 \%)$. The difference, $2.11 \%$, is quite considerable. ${ }^{7}$

Moreover, if anything, the puzzle has increased over time. Our estimates indicate that the average total return on assets during the Bretton Woods period (4.04\%) was only 26 basis point larger than the average total return on gross liabilities (3.78\%). Since 1973, however, the gap has widened enormously. The post Bretton Woods average asset return is $6.82 \%$ while the corresponding total liability return is only $3.50 \%$. The excess return reaches an astonishing $3.32 \%$ (see figure 7 ). Hence, the 'exorbitant privilege' puzzle is reinforced when one looks at total returns.

We can use these historical averages to assess the tipping point beyond which we should expect the US to pay more on its gross liabilities than it earns on its gross assets. The calculation, first proposed by Obstfeld and Taylor (2005), goes as follows. The tipping point is defined as that ratio of gross liabilities to gross assets beyond which $\tilde{r}^{a} A-\tilde{r}^{l} L$ becomes negative, where $\tilde{r}^{a}$ (resp. $\tilde{r}^{l}$ ) denotes an estimate of the nominal average total return on gross assets $A$ (resp. liabilities $L$ ).

\footnotetext{
${ }^{7}$ These returns are reported in Table 1 . For a study disentangling the effect of capital gains, investment flows and trade balance on the accumulation of net foreign assets of different countries see Lane and Milesi-Ferretti (2005).
} 


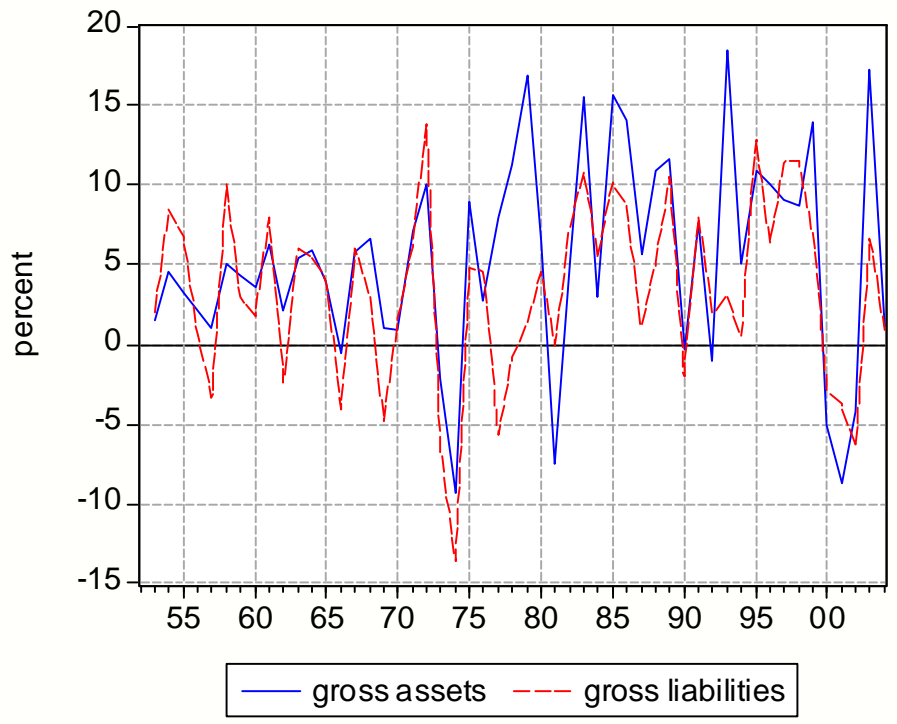

Figure 7: Annual real return on gross assets and gross liabilities. 1952-2004.

Using the nominal historical values of $\tilde{r}^{a}$ and $\tilde{r}^{l}$, we estimate a tipping point $L / A>\tilde{r}^{a} / \tilde{r}^{l}=$ $1.30 .^{8}$ The implication of the 'exorbitant privilege' is that a two percent excess return allows the US to accumulate debt exceeding its gross assets by $30 \%$ and yet still be a recipient of positive investment income. Since the exorbitant privilege of the US has increased over time, the tipping point has also been pushed back substantially. Calculated using the average returns over the Bretton Woods period, we estimate a tipping point of only 1.04. Using the post Bretton Woods period estimates of returns, the tipping point now reaches an astonishing 1.43.

Interestingly, our estimates of the net foreign asset position of the US suggest that the leverage ratio $L / A$ has increased steadily over the period from 0.3 in 1952 to 0.73 in 1973, reached 1.09 in 1991, and finally 1.34 in 2004. Hence, the U.S. may be getting close to the position where it will have to start making net payments to the rest of the world.

Of course, this simple computation ignores the endogeneity of the returns on gross assets and liabilities. Reaching the "tipping point" where the US for the first time since the second World War ceases to have a positive net return on its net assets could be seen by the market as a significant blow to the credibility of the dollar. In a context where the external net worth of the US is negative

\footnotetext{
${ }^{8}$ The values of the nominal returns on assets and liabilities $\tilde{r}^{a}$ and $\tilde{r}^{l}$ are respectively: for the whole sample $9.15 \%$ and 7.04\%; for Bretton Woods: 6.32\% and 6.06\%; for the post -Bretton Woods period: $11.00 \%$ and $7.69 \%$.
} 
and the return on its net assets also turns negative, market participants could start demanding a higher premium on their dollar assets, thereby setting off unstable dynamics. This may also affect the structure of market participants' borrowing: for example they could start to coordinate on another international currency, such as the euro, to provide liquidity. They could also abandon short-term low-yield US securities such as T-Bills for higher yielding assets (equity, FDI). ${ }^{9}$ This would considerably change the external balance sheet of the US and narrow the gap between the total return on US assets and liabilities, further deepening the adjustment problem. As the gap between the return on gross assets and gross liabilities declines, the net interest burden would rise rapidly, setting off further moves away from US assets. While this is a possible scenario, we stress that understanding the dynamics of the composition of international portfolios, asset returns and the exchange rate requires a dynamic general equilibrium model of the world economy, which is well beyond the scope of this paper.

\section{The Exorbitant Privilege Part II: US as World Venture Capi- talist}

\subsection{Composition of the gross asset and liability position.}

We now turn our attention to the structure of gross assets and liabilities and its evolution over time. This structure is particularly interesting in the case of the US, which has been the center country of the Bretton Woods system since 1944 and has remained the most important financial center in the world, even after the collapse of the fixed exchange rate regime.

The US has succeeded the United Kingdom as the 'Banker of the World' and the issuer of the main international currency. This means in particular being able to borrow short (foreigners are willing to purchase liquid dollar assets) and lend long (the US supplies long-term loans and investment funds to foreign enterprises). Just like a bank, the US can extract an intermediation margin, given by the (positive) return differential between external assets and liabilities. During the whole period, US assets have shifted more and more out of long term bank loans towards FDI and, since the 1990s, towards FDI and equity. At the same time, its liabilities have remained

\footnotetext{
${ }^{9}$ Witness the recent attempts by China to move away from US treasuries and into direct investment (Maytag, Unocal, IBM).
} 


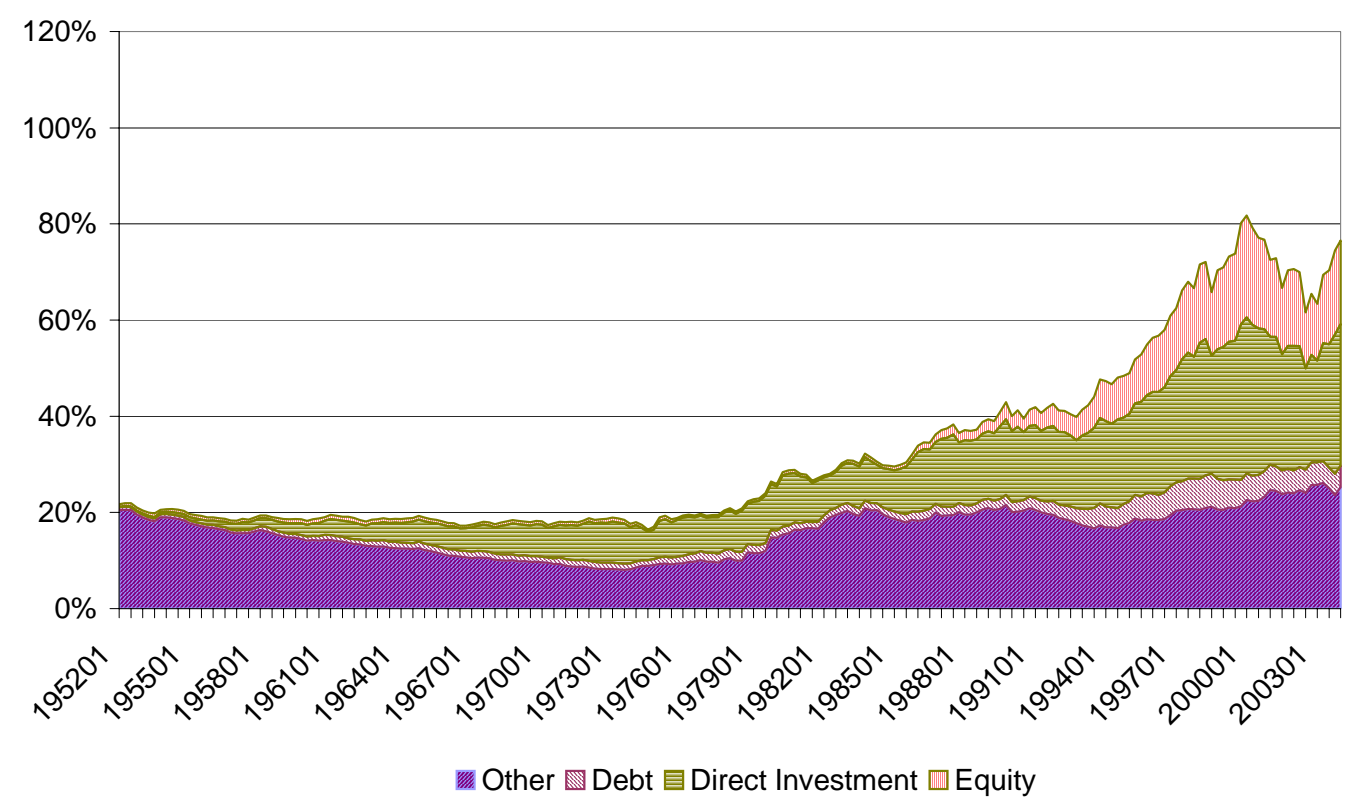

Figure 8: U.S. Gross External Assets (share of GDP), 1952-2004. Source: Author's Calculations.

dominated by bank loans, trade credit and debt, i.e. low yield safe assets. Hence the US balance sheet resembles increasingly one of a venture capitalist with high return risky investments on the asset side. Furthermore, its leverage ratio has increased sizably over time.

The currency denomination of securities is also rather specific. The issuer of the international currency is able to denominate its entire stock of liabilities in dollars, thereby shifting the exchange rate exposure to the rest of the world. This key characteristic of the external balance sheet of the US, shared to some extent by other developed countries, is instrumental in the stabilization of the external accounts of these countries. As pointed out in Gourinchas and Rey (2005), a depreciation of the US dollar has two beneficial effects on the external position. It helps to increase net exports (trade adjustment channel), and it also increases the dollar value of US assets (valuation channel).

Figures 8 and 9 present our estimates of the ratio of each asset class to GDP. Several interesting episodes can be read from these graphs: (i) the petrodollar recycling in the 70s until the Latin American debt crisis of 1982 (see the large increase in 'other assets' -mostly bank loans over that period- followed by a stagnation and a decrease); (ii) the erosion of the home bias in equity portfolios at the end of the 1990s (particularly spectacular in the US asset portfolio); (iii) the bursting of the equity market bubble in 2000-01 (which affects both the US gross assets and liabilities). 


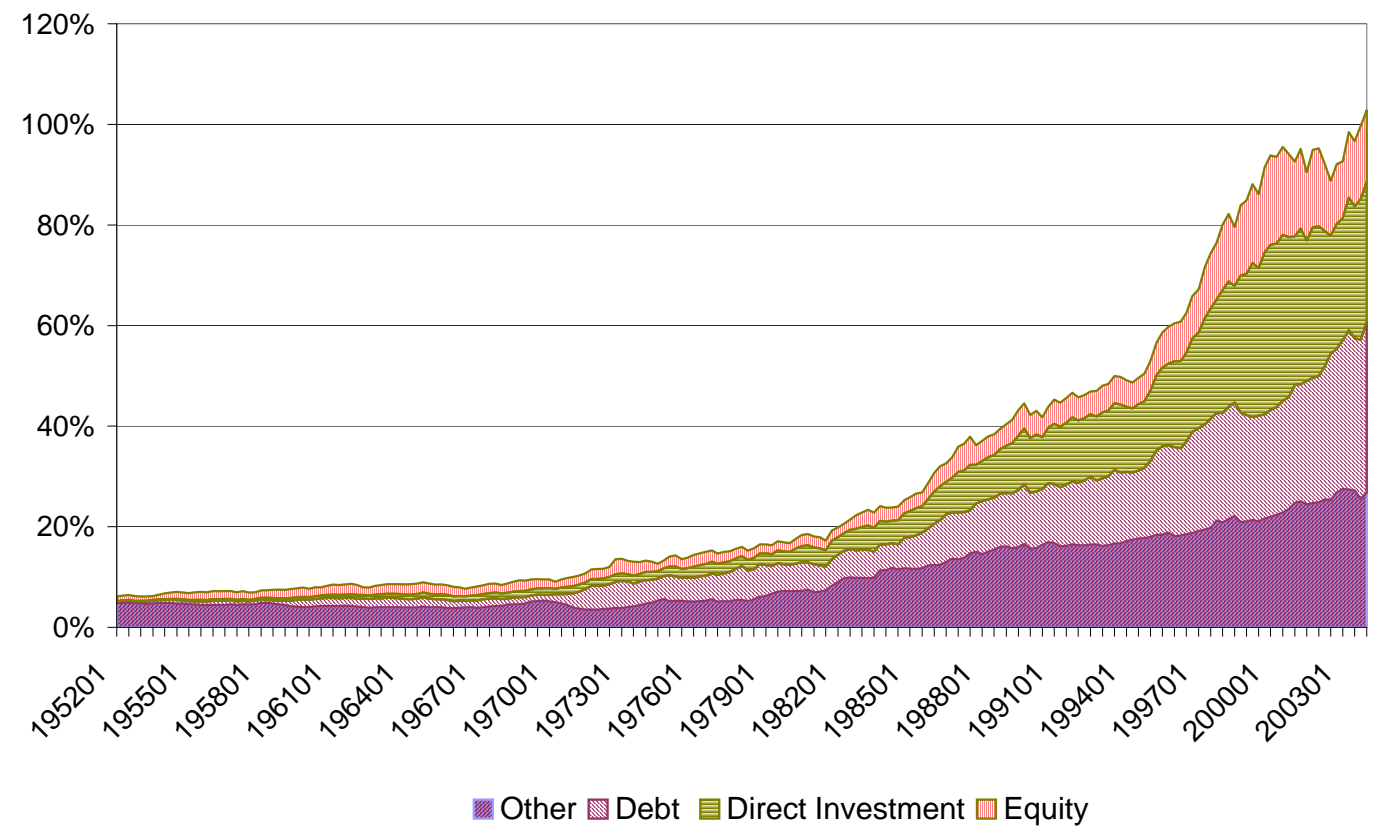

Figure 9: U.S. Gross External Liabilities (share of GDP), 1952-2004. Source: Author's Calculations.

During the 1960s, the US was running moderate current account surpluses but was investing sizable amounts abroad in the form of FDI. The share of FDI steadily increased between 1952 and 1973, from zero to $40 \%$ of gross external asset positions. On 4 February 1965 the French president de Gaulle famously complained in a press conference at the Elysée Palace that an increase in the US money supply was leading to increased capital outflows from the US and "for some countries to a sort of expropriation of their enterprises." For de Gaulle, the role of the dollar as the international currency meant that the US could borrow money from the rest of the world "free of charge." By printing dollars and using them to purchase foreign companies, it was claimed, the US was abusing its hegemonic position at the center of the international monetary system. But these long- term capital outflows led to a continuous drain of the US gold reserves, despite the numerous and futile attempts by the US to limit the size of the balance of payments deficit. This is visible in Figure 8 where a sharp increase in FDI assets is matched almost one for one by a decrease in "other" assets. As figure 10 documents, a substantial share of the decline in other assets was due to the drain on US gold reserves. Successive US administrations used various expedients such as the interest equalization tax, "voluntary" restraint programs, restrictions on tourism, offset agreements and sheer political pressure on foreign central banks (especially the Bundesbank and the Bank of 


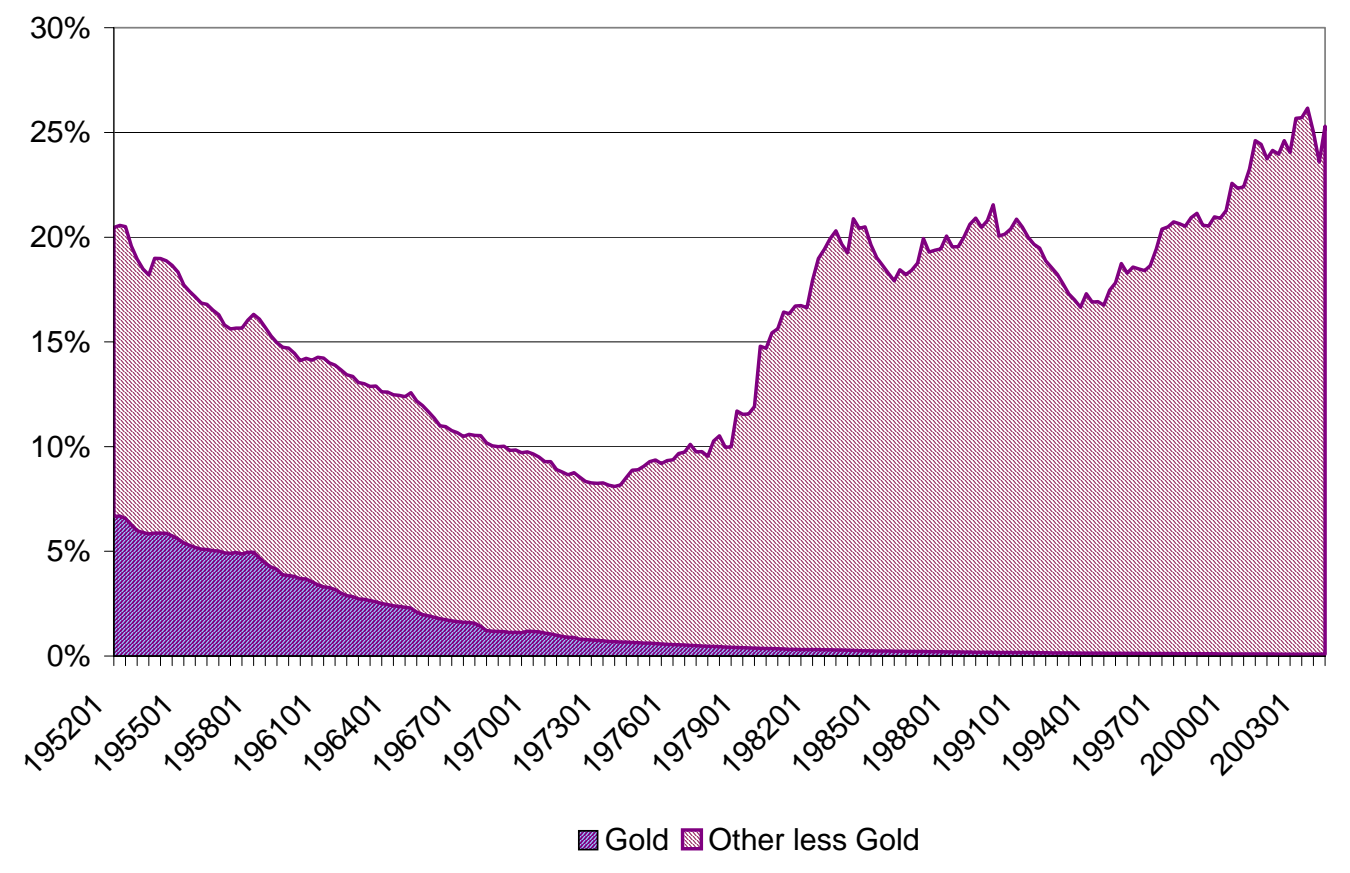

Figure 10: US Other Gross Assets and Gold (share of GDP), 1952-2004.

Japan) to prevent dollars held abroad from being converted into gold. Despite these interventions, the credibility of the convertibility of the dollar waned over time and the tensions on the foreign exchange markets culminated in 1970 and 1972-73 with successive runs on the dollar that triggered the collapse of the fixed exchange rate system of Bretton Woods.

The abandonment of gold parity, however, did not lead to the demise of the dollar as the main international currency. ${ }^{10}$ The US has remained the world liquidity provider ever since. As shown in Figure 11 the share of liquid liabilities (defined as debt, trade credits and bank loans) in total US liabilities has gone down only slightly from roughly $70 \%$ in 1973 to around $60 \%$ in 2004 (the decrease of the end of the 1990s is due to the equity bubble). This constitutes a remarkably high share of total liabilities and reflects the high demand in the rest of the world for liquid US securities as a transaction medium, reserves or store of value both during Bretton Woods and after the collapse of the fixed exchange rate regime.

Over the same period, the share of high yield risky investment increased considerably. From a conservative world banker, the US became a bold world venture capitalist. The share of risky assets

\footnotetext{
${ }^{10}$ See Portes and Rey (1998) for a review of the dominant position of the US dollar in the international monetary system.
} 


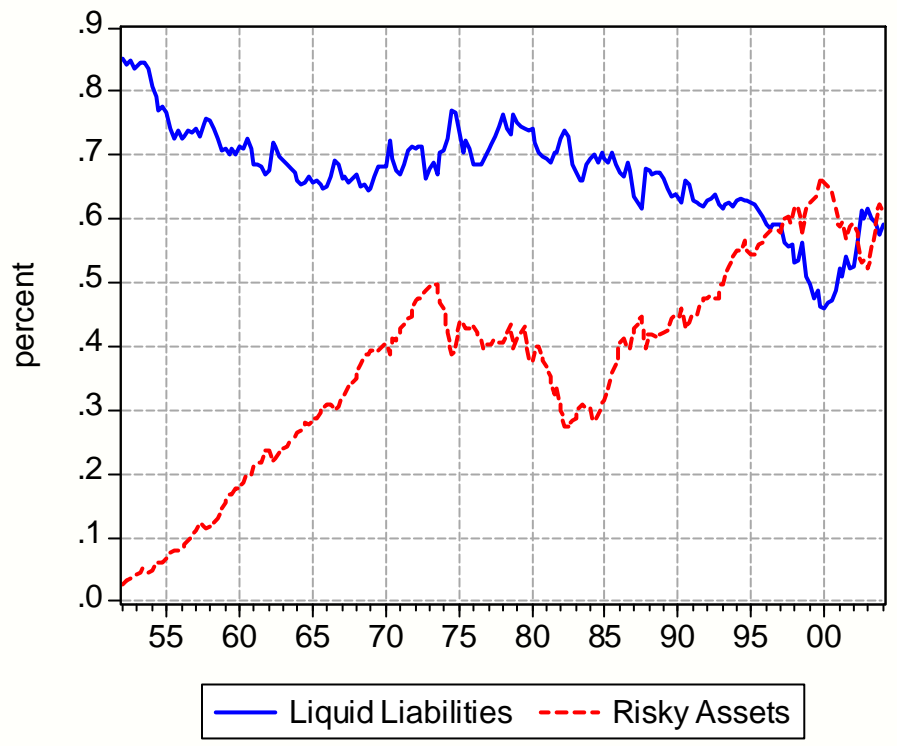

Figure 11: Share of risky assets in all assets, share of liquid liabilities in all liabilities (1952-2004).

in total assets increased continuously during the Bretton Woods era, as growing FDI outflows led to a decrease in gold reserves. This gold drain was stopped in 1973 once the Nixon Administration decided to end the convertibility of the dollar. After the emerging market debt crisis of the 1980s and the deregulation of equity markets of the 1990s, the growth in FDI and portfolio equity flows gathered pace so that by 2004, the share of risky assets in the total asset portfolio of the US reached about $60 \%$, against roughly $50 \%$ in 1973 . Hence the collapse of Bretton Woods has not deprived the US of its fundamental role as world liquidity provider. This upward trend in the share of high yielding risky assets is consistent with the increase over time of the (positive) return differential between assets and liabilities, as documented in the previous section. ${ }^{11}$

\subsection{Total returns}

The yields that the US receivess on its external assets are higher that the yields that it pays on its liabilities. In the previous section, we showed that this is also true for the aggregate total returns on the net foreign asset position of the US. We now look at total returns on gross assets and liabilities and on each class of assets independently. Table 1 presents estimates of average total real annual

\footnotetext{
${ }^{11}$ It would be of great interest to compare the balance sheet of the US to those of other developed countries more precisely. This is the undertaking of Obstfeld and Taylor (2005).
} 


\begin{tabular}{|c|c|c|c|c|c|c|c|c|c|c|}
\hline \multirow{2}{*}{$\begin{array}{l}\text { Panel 1a } \\
\text { Total real returns }\end{array}$} & \multicolumn{10}{|c|}{ Summary Statistics (1952:1-2004:1) } \\
\hline & $r^{a}$ & $r^{l}$ & $r^{a e}$ & $r^{a f}$ & $r^{a d}$ & $r^{a O}$ & $r^{l e}$ & $r^{l f}$ & $r^{l d}$ & $r^{l o}$ \\
\hline Mean $(\%)$ & 5.72 & 3.61 & 13.68 & 9.57 & 4.35 & 3.43 & 10.28 & 9.56 & 0.51 & 1.19 \\
\hline St. Deviation (\%) & 11.98 & 10.49 & 39.76 & 23.10 & 15.94 & 9.33 & 36.70 & 24.18 & 13.09 & 4.91 \\
\hline Sharpe Ratio (\%) & 47.73 & 34.40 & 34.39 & 41.43 & 27.31 & 36.78 & 28.02 & 39.56 & 3.87 & 24.29 \\
\hline Panel 1b & \multicolumn{10}{|c|}{ Summary Statistics (1952:1-1973:1) } \\
\hline Total real returns & $r^{a}$ & $r^{l}$ & $r^{a e}$ & $r^{a f}$ & $r^{a d}$ & $r^{a O}$ & $r^{l e}$ & $r^{l f}$ & $r^{l d}$ & $r^{l o}$ \\
\hline Mean (\%) & 4.04 & 3.78 & 10.83 & 9.44 & 4.82 & 2.40 & 11.59 & 9.96 & 0.80 & 1.24 \\
\hline St. Deviation (\%) & 4.79 & 9.60 & 36.83 & 16.32 & 17.67 & 1.75 & 36.29 & 21.33 & 10.66 & 1.32 \\
\hline Sharpe Ratio (\%) & 84.51 & 39.34 & 29.41 & 57.85 & 27.29 & 137.10 & 31.93 & 46.68 & 7.47 & 94.63 \\
\hline Panel 1c & \multicolumn{10}{|c|}{ Summary Statistics (1973:1-2004:1) } \\
\hline Total real returns & $r^{a}$ & $r^{l}$ & $r^{a e}$ & $r^{a f}$ & $r^{a d}$ & $r^{a o}$ & $r^{l e}$ & $r^{l f}$ & $r^{l d}$ & $r^{l o}$ \\
\hline Mean (\%) & 6.82 & 3.50 & 15.54 & 9.65 & 4.05 & 4.11 & 9.43 & 9.31 & 0.32 & 1.16 \\
\hline St. Deviation (\%) & 14.84 & 11.07 & 41.61 & 26.69 & 14.77 & 11.89 & 37.09 & 25.96 & 14.50 & 6.24 \\
\hline Sharpe Ratio (\%) & 45.91 & 31.60 & 37.35 & 36.16 & 27.40 & 34.54 & 25.43 & 35.85 & 2.19 & 18.58 \\
\hline
\end{tabular}

Table 1: Descriptive Statistics: Average quarterly total real returns (annualized)

returns on the different subcomponents of assets and liabilities for the whole sample, the Bretton Woods period and the Floating Exchange Rate Regime. ${ }^{12}$ We denote by $r^{a}$, the return on gross assets, $r^{l}$ the return on gross liabilities, $r^{a e}$ the return on equities, $r^{a d}$ the return on debt, $r^{a f}$ the return on FDI and $r^{a o}$ the return on "others" (all returns are real). Symmetrically, $r^{l e}$ denote the return on foreigners' holdings of US equity (in other words, US equity liabilities), $r^{l f}$ the return on FDI liability, $r^{l d}$ and $r^{l o}$ the return on debt and other liability respectively.

Several features are noteworthy. First, as we already mentioned, over the whole period, the US gained a sizable excess return in real terms on assets over liabilities $(2.11 \%=5.72 \%-3.61 \%)$. This excess return is especially large during the floating exchange rate period (between 1973 and 2004, it is equal to $3.32 \%$ in real terms). Considering each asset in turn, the US earns an average of 340 bp excess return yearly on its equity assets ( $r^{a e}$ vs $\left.r^{l e}\right), 384 \mathrm{bp}$ on its debt ( $r^{a d}$ vs $\left.r^{l d}\right)$ and 214 bp on its bank loan and trade credits $\left(r^{a o}\right.$ vs $\left.r^{l o}\right)$. By contrast, the US does not seem to enjoy sizable superior returns on its direct investment abroad. The excess return is only one bp $\left(r^{a f}\right.$ vs $\left.r^{l f}\right)$.

Second, there is a sizable gap between returns on the "safe assets" (debt and others) and the returns on risky assets (equity and FDI). During the 1950s and the 1960s, foreigners earned a very

\footnotetext{
${ }^{12}$ See Appendix B.3 for details on how we computed the returns.
} 
low real return on US debt ( $0.80 \%$ on average): de Gaulle was not that far off when he was talking of the US debt being "free of charge". With the advent of the floating exchange rate regime, the real returns on debt became even lower $(0.32 \%$ on average).

Third, the volatility of all returns has increased significantly after the collapse of Bretton Woods so that the sharpe ratios of assets have in general declined during the floating exchange rate regime.

\subsection{A break-up of total returns}

The large positive excess real return of gross assets over gross liabilities can be broken up into a composition effect and a return effect. US liabilities are dominated by low yield safe securities whereas US assets contain a large (and increasing over time) share of FDI and equity. The US can be therefore characterized as a very leveraged investor, which is increasingly shorting low-yield securities to buy high-yield investments. This is the composition effect. But there is also a return effect. Within each class of assets, the preceding discussion showed that the US earned higher returns on its assets than on its liabilities. This price effect represents the other dimension of the 'exorbitant privilege' and could occur in particular because of a liquidity discount for the issuer of the international currency, as discussed in Portes and Rey (1998). Formally, we can decompose the return on assets $r^{a}$ and the return on liabilities $r^{l}$ as:

$$
\begin{aligned}
r^{a} & =\mu^{a e} r^{a e}+\mu^{a d} r^{a d}+\mu^{a f} r^{a f}+\mu^{a o} r^{a o} \\
r^{l} & =\mu^{l e} r^{l e}+\mu^{l d} r^{l d}+\mu^{l f} r^{l f}+\mu^{a l} r^{l o}
\end{aligned}
$$

where $\mu^{a e}, \mu^{a f}, \mu^{a o}$ and $\mu^{a d}$ are the weights on equity, FDI, other foreign assets (bank loans and trade credit) and debt in total assets. Notations for the liability side are defined in an entirely symmetric fashion.

We can then write the expected excess return of assets over liabilities as:

$$
\begin{aligned}
E\left(r^{a}-r^{l}\right)= & E\left[\bar{\mu}^{o}\left(r^{a o}-r^{l o}\right)\right]+E\left[\bar{\mu}^{d}\left(r^{a d}-r^{l d}\right)\right]+E\left[\bar{\mu}^{e}\left(r^{a e}-r^{l e}\right)\right]+E\left[\bar{\mu}^{f}\left(r^{a f}-r^{l f}\right)\right] \\
& +E\left[\left(\mu^{a d}-\mu^{l d}\right)\left(\bar{r}^{d}-\bar{r}^{o}\right)\right]+E\left[\left(\mu^{a e}-\mu^{l e}\right)\left(\bar{r}^{e}-\bar{r}^{o}\right)\right]+E\left[\left(\mu^{a f}-\mu^{l f}\right)\left(\bar{r}^{f}-\bar{r}^{o}\right)\right]
\end{aligned}
$$




\begin{tabular}{|c|c|c|c|c|c|c|c|c|c|c|}
\hline & \multicolumn{5}{|c|}{ Return effect } & \multicolumn{4}{|c|}{ Composition Effect } & Total \\
\hline & (1) & $(2)$ & (3) & $\overline{(4)}$ & Total & $(5)$ & (6) & $\overline{~(7)}$ & Total & $\overline{c r^{a}-r^{l}}$ \\
\hline Period & Other & Debt & Equity & FDI & (1) to $(4)$ & Debt & Equity & FDI & (5) to $(7)$ & (1) to $(7)$ \\
\hline $1952-2004$ & 1.00 & 0.56 & 0.35 & 0.06 & 1.97 & 0.03 & -0.59 & 0.70 & 0.14 & 2.11 \\
\hline 1952-1973 & 0.69 & 0.38 & 0.04 & 0.12 & 1.23 & -0.23 & -1.46 & 0.73 & -0.96 & 0.27 \\
\hline 1973-2004 & 1.21 & 0.68 & 0.55 & 0.01 & 2.45 & 0.20 & -0.02 & 0.68 & 0.86 & 3.32 \\
\hline
\end{tabular}

Table 2: Break-up of Total Real Returns in a Price and a Composition Effect

where $E$ denotes the expectation sign, $\bar{\mu}^{i}=\left(\mu^{a i}+\mu^{l i}\right) / 2$ is the average portfolio share for asset class $i$ and $\bar{r}^{i}=\left(r^{a i}+r^{l i}\right) / 2$ is the average return on asset class $i$. The first four terms represent the return effect. They denote the average excess return on external assets relative to liabilities within each class of assets. This return effect is zero if the return is the same within each asset $\operatorname{class}\left(r^{a i}=r^{l i}\right)$.

The last three terms represent the composition effect. It quantifies the difference in weights between assets and liabilities for equity, FDI and debt. The composition effect is zero if US external assets have the same composition as US external liabilities $\left(\mu^{a i}=\mu^{l i}\right) .{ }^{13}$

In Table 2, we analyze the relative importance of the composition and return effects in explaining the high return enjoyed by the US on its net foreign asset position. All the returns are in percentage terms.

We first observe that the return effect plays a dominant part in explaining the excess return of the US net foreign asset portfolio. We find that it accounts for 1.97 percent of the 2.11 percent total excess return over the entire sample, 1.23 percent during the Bretton Woods period and 2.45 percent since 1973. The return effect is especially significant for the short term liquid assets (other and debt) where it accounts for about half of the total excess return (1.56 percent of the total 2.11 percent). It is smaller in the other asset classes, although it remains positive for all asset classes on all subsamples.

\footnotetext{
${ }^{13}$ The shares $\mu^{a i}$ and $\mu^{l i}$ are time-varying. Hence the overall excess return depends also upon the covariance between asset returns and shares.
} 
The composition effect plays a smaller role over the entire sample (0.14 percent), but its relevance has increased significantly over time, from -0.96 percent before 1973 to 0.86 percent since then. Hence, between a quarter and a third of the current excess return (3.32 percent) can be explained by the asymmetry in the US external balance sheet and the fact that the US earns an equity premium. Looking at the subcomponents of this composition effect, we find that most of it arises from the asymmetry in direct investment ( 0.70 percent). The increased contribution of the composition term, however, reflects mostly the increased symmetry in equity positions (from -1.46 percent to -0.02 percent) reflecting the decrease of home bias in US portfolios (the share of foreign equity in US portfolios has risen over time).

\section{Exchange rate adjustment}

Current external imbalances can be compensated either by future trade surpluses or by future favorable returns on the net foreign asset position of the US. In this section, we perform a simple exercise, meant to illustrate the joint capacity of the valuation channel and of the more traditional trade channel to stabilize the external accounts of the US. Gourinchas and Rey (2005) show that the valuation channel operates at short to medium horizons while the trade channel operates in the medium to long run. Historically the valuation channel has contributed around $30 \%$ of the process of international adjustment.

\subsection{Theory}

We start from the law of accumulation of foreign assets between $t$ and $t+1$ :

$$
N F A_{t+1} \equiv R_{t+1} N F A_{t}+N X_{t+1}
$$

where $N X_{t}$ represents net exports, defined as the difference between exports $X_{t}$ and imports $M_{t}$ and net foreign assets $N F A_{t}$ is defined as the difference between gross foreign assets $A_{t}$ and gross foreign liabilities $L_{t}$, measured in domestic currency at the end of period $t$. Equation (1) states that the net foreign position increases with net exports and with the total return on the net foreign asset portfolio $R_{t+1}$. Dividing through by US GDP $Y_{t}$, and using lower case letters to 
denote normalized variables (so that $n f a_{t}=N F A_{t} / Y_{t}$ ), we obtain:

$$
n f a_{t+1}=\frac{R_{t+1}}{g_{t+1}} n f a_{t}+n x_{t+1}
$$

where $g_{t+1}$ represents the growth rate of output between $t$ and $t+1$.

Net exports and the return on the net foreign asset positions are both affected by movements in the exchange rate. In the case of the US, a dollar depreciation helps on both counts. It stimulates net exports and it increases the dollar value of US assets thereby improving the return on the net foreign asset position. This is because most US liabilities are in dollars whereas a share of US assets are in foreign currency. ${ }^{14}$ We estimate the magnitude of a devaluation needed, ceteris paribus, for the US net foreign debt and the US net exports to satisfy the following long run equilibrium (steady state) condition, obtained from equation (1):

$$
n x=\left(1-\frac{R}{g}\right) n f a
$$

where variables without time subscript denote steady state values. Numerically, we equate $g$ to the historical average of real GDP growth (1.033 per year in gross term). $R$ is the steady state rate of return on the net foreign asset position. From Gourinchas and Rey (2005), we know that $R=g / \rho$ where $\rho$ is a growth-adjusted discount factor, a function of steady state weights on exports, imports, assets and liabilities. Empirically, Gourinchas and Rey (2005) found that $\rho=0.95$. Hence we assume that $R=1.033 / 0.95=1.0874$ (the net steady state return on the net foreign asset position is therefore equal to $8.74 \%$ ). Given these estimates, we find a long run ratio of net exports to net foreign assets equal to $n x / n f a=1-R / g=-5.26 \%$.

Next, we need to quantify the effect of an exchange rate depreciation on net exports and on the net foreign asset portfolio return. Estimates in the literature imply that a $1 \%$ increase in the ratio of net exports to GDP requires a depreciation of 11 to $20 \%$ of the exchange rate (see Blanchard, Giavazzi and Sa (2005)). We pick two estimates: a middle range estimate of $15 \%$ and a low estimate of $10 \%$. Hence we assume

$$
d n x=\eta \frac{d e}{e}
$$

\footnotetext{
${ }^{14}$ In constrast, for an emerging market with dollarized liabilities, a depreciation will be destabilizing.
} 
where $\eta$ is taken to be $1 / 15$ or $1 / 10$.

We now assess the effect of a change in the exchange rate on the first term on the right hand side of (2). Using the definition of $R_{t+1}$, we can write

$$
R_{t+1} n f a_{t}=r_{t+1}^{a} a_{t}-r_{t+1}^{l} l_{t}
$$

In the absence of a general equilibrium model of portfolio allocation and equilibrium returns, we make the assumption that the asset composition of the net foreign asset position remains constant relative to GDP over the period considered. Hence the response of the net foreign asset position to changes in the exchange rate is solely determined by the response of the returns on assets and liabilities to exchange rate changes:

$$
d R_{t+1} n f a_{t}=d r_{t+1}^{a} a_{t}-d r_{t+1}^{l} l_{t}
$$

We use historical data of the floating exchange rate period to estimate the elasticity of the dollar returns on gross assets and liabilities to the exchange rate for a given horizon $h$. To do so, we estimate regressions of the form:

$$
\begin{aligned}
& r_{t, h}^{a}=\bar{r}_{h}^{a}+\beta_{a}^{h} \frac{d e_{t, h}}{e_{t, h}} \\
& r_{t, h}^{l}=\bar{r}_{h}^{b}+\beta_{l}^{h} \frac{d e_{t, h}}{e_{t, h}}
\end{aligned}
$$

where $r_{t, h}^{a}$ denotes the annualized net returns on gross assets and $r_{t, h}^{l}$ the annualized net return on gross liabilities at horizon $h$ while $d e_{t, h} / e_{t, h}$ is the annualized rate of depreciation between $t$ and $t+h$. These regressions use quarterly data for the 1973-2004 sample. The results are reported in Table 3, for horizons between 1 and 5 years, with standard errors in parentheses.

We find that depreciations are associated with significantly larger returns on gross assets and (marginally significantly) lower returns on gross liabilities. This indicates potentially powerful valuation effects. 


\begin{tabular}{l|lll|l|lll} 
& \multicolumn{3}{|l|}{ Horizon $h$ (years) } & \multicolumn{3}{l}{ Horizon $h$ (years) } \\
\hline \hline$h=$ & 1 & 3 & 5 & $h=$ & 1 & 3 & 5 \\
$\beta_{a}^{h}$ & 0.28 & 0.26 & 0.19 & $\beta_{l}^{h}$ & -0.08 & -0.15 & -0.14 \\
s.e. & $(0.10)$ & $(0.09)$ & $(0.08)$ & s.e. & $(0.08)$ & $(0.09)$ & $(0.09)$ \\
$\bar{r}_{h}^{a}$ & $6.64 \%$ & $6.96 \%$ & $7.52 \%$ & $\bar{r}_{h}^{l}$ & $3.6 \%$ & $4.04 \%$ & $4.44 \%$ \\
(annualized) & & & & (annualized) & & & \\
\hline
\end{tabular}

Table 3: Elasticities of Asset and Liability Returns to Exchange Rate Changes

Given these (admittedly) reduced-form relations, we can now estimate the magnitude of the depreciation needed for the US to satisfy the steady state relation linking its net foreign asset position to its net exports within an horizon of $h$ years. To do so, we start by writing the accumulation equation (2) between $t$ and $t+h$ :

$$
n f a_{t+h}=\prod_{j=1}^{h}\left(\frac{R_{t+j}}{g_{t+j}}\right) n f a_{t}+\sum_{j=1}^{h} n x_{t+j} \prod_{i=j}^{h-1}\left(\frac{R_{t+i+1}}{g_{t+i+1}}\right)
$$

Assuming that we reach the steady state in $t+h$, so that $n f a_{t+h}=n f a$ and $n x_{t+h}=n x$, and assuming that the growth rate of the economy is constant along this transition and equal to $g$, we obtain: ${ }^{15}$

$$
n f a \approx g^{-h}\left[\left(\bar{r}_{h}^{a}+\beta_{a}^{h} h \frac{d e}{e}\right) a_{t}-\left(\bar{r}_{h}^{l}+\beta_{l}^{h} h \frac{d e}{e}\right) l_{t}\right]+n x_{t} \frac{1-(R / g)^{h}}{1-R / g}+\eta \frac{d e}{e} \sum_{j=1}^{h} j\left(\frac{R}{g}\right)^{h-j}
$$

The first term on the right hand side reflects the impact of the change in the exchange rate on the net foreign asset position (the valuation effect). The second term represents the cumulated impact of the depreciation on the trade balance (the trade balance effect).

Finally, we observe that in the steady state $n f a=n x /(1-R / g)=\left[n x_{t}+h \eta d e / e\right] /(1-R / g)$. Putting everything together, we can solve for the annual depreciation rate that restores the long run external balance in $h$ years:

$$
\frac{d e}{e}=\left[\frac{h \eta}{1-\frac{R}{\gamma}}-g^{-h} h\left(\beta_{a}^{h} a_{t}-\beta_{l}^{h} l_{t}\right)-\eta \sum_{j=1}^{h} j\left(\frac{R}{g}\right)^{h-j}\right]^{-1}\left[g^{-h}\left(\bar{r}_{h}^{a} a_{t}-\bar{r}_{h}^{l} l_{t}\right)-n x_{t} \frac{(R / g)^{h}}{1-R / g}\right]
$$

The required rate of depreciation depends upon the horizon $h$, the trade elasticity $\eta$, the semi-

\footnotetext{
${ }^{15}$ This assumes that the growth rate of the US economy is unaffected by the change in the exchange rate. Obviously, this is a strong assumption.
} 


\begin{tabular}{|c|c|c|c|}
\hline & \multicolumn{3}{|c|}{ Horizon $h$ (years) } \\
\hline \multirow[t]{2}{*}{$h=$} & 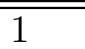 & & 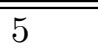 \\
\hline & \multicolumn{3}{|c|}{$\eta=1 / 15$} \\
\hline Annual depreciation to & & & \\
\hline Long run equilibrium (percent) & 74.6 & 26.3 & 17.8 \\
\hline $\begin{array}{l}\text { Long run trade balance } \\
\text { (percent, relative to GDP) }\end{array}$ & 0.18 & 0.46 & 1.15 \\
\hline \multirow{2}{*}{$\begin{array}{l}\text { Long run Net Foreign Asset position } \\
\text { (percent, relative to GDP) }\end{array}$} & -3.3 & -8.7 & -21.9 \\
\hline & \multicolumn{3}{|c|}{$\eta=1 / 10$} \\
\hline Annual depreciation to & 52.9 & 18.7 & 12.6 \\
\hline Long run equilibrium (percent) & & & \\
\hline $\begin{array}{l}\text { Long run trade balance } \\
\text { (percent, relative to GDP) }\end{array}$ & 0.49 & 0.82 & 1.48 \\
\hline $\begin{array}{l}\text { Long run Net Foreign Asset position } \\
\text { (percent, relative to GDP) }\end{array}$ & -9.3 & -15.6 & -28.1 \\
\hline
\end{tabular}

Table 4: Depreciations required to go to the long run equilibrium

elasticity of returns to the exchange rate $\left(\beta_{a}^{h}\right.$ and $\left.\beta_{l}^{h}\right)$ as well as the initial trade balance $\left(n x_{t}\right)$ and gross foreign asset positions $\left(a_{t}\right.$ and $\left.l_{t}\right)$.

\subsection{Numerical Application}

We use data from 2004 for the net foreign asset to GDP ratio $\left(n a_{t}=-26 \%\right)$, the net export to GDP ratio $\left(n x_{t}=-4.8 \%\right)$, the ratio of gross assets over GDP $\left(a_{t}=76 \%\right)$ and the ratio of gross liabilities over GDP $\left(l_{t}=103 \%\right)$. Returns and elasticity of returns to exchange rate changes are taken from Table 3 for the relevant horizon.

Table 4 reveals that a return to equilibrium in one year would require an implausible depreciation of 75 percent. Such a large depreciation would turn around the trade balance from -4.8 percent to 0.18 percent. However, the main direct effect of the that depreciation would be to wipe out most of the net foreign liabilities of the US. The long run net foreign assets would stabilize around -3.3 percent. Of course, it is rather implausible that the asset composition of international portfolios would remain constant in the face of such a major change in relative prices.

Going back to the long run equilibrium in three years instead would require a depreciation of 26 percent per year while a return to equilibrium in five years would requires a depreciation of 18 
percent per year. An extended adjustment period implies that the US would be running current account deficits -and accumulate foreign debt- for a longer time. This has two implications. First, the long run value of the net foreign debt remains quite substantial. In fact, we find that if the adjustment takes five years, the net foreign debt will still represent 22 percent of GDP, only slightly down from its current value of 26 percent. Second this requires a more substantial turnaround in next exports. We find that the trade balance would have to reach a surplus of 0.46 percent each year at a three year horizon, or 1.15 percent at five years.

A higher elasticity of exports allows for a smaller depreciation of the exchange rate. When $\eta=1 / 10$, the depreciation at one year is 'only' $53 \%$, and drops to $13 \%$ per year for a five year adjustment. The equilibrium trade balance exhibits a larger surplus and the net foreign asset debt remains comparably larger (28\% at 5 years).

There is of course no theoretical reason to assume that the US net foreign asset position should go back to its long run equilibrium in one or three or five years. In Gourinchas and Rey (2005) we base our forecasts of exchange rate depreciation on historical adjustment speeds and predict smaller rates of depreciation. But the type of exercise that we have undertaken here could be seen as estimating the necessary exchange rate depreciation in the event of exogenous shocks on capital flows that could force the US net foreign asset position to adjust suddenly. ${ }^{16}$

\section{Concluding Remarks: Current Issues in Light of the Bretton Woods Debates.}

The main objective of this paper is to bring new data to bear on the question of the external adjustment process of the US. We constructed a quarterly dataset of US external assets and liabilities at market value going back to 1952. We showed that the US has always faced a weakened external constraint. In particular, it has consistently been able to borrow on quite favorable terms and earn a significant premium on its provision of global liquidity. Perhaps surprisingly, this ability has strengthened over time, despite the runs on the dollar of the seventies and the demise of the fixed exchange rate system.

\footnotetext{
${ }^{16}$ See Obstfeld and Rogoff (2004) for another example.
} 
In this context, we find it instructive to revisit the intellectual debates of the 1960s regarding the US 'balance of payments problem'. We are certainly not the first ones to point out interesting parallels between the challenges of the Bretton Woods system and the current global imbalances (see Dooley, Folkerts-Landau and Garber (2003), Eichengreen (2004)). Our contribution is merely to point out what our revised estimates of the US external positions have to say about both historical and current debates.

Broadly speaking, we identify three strands of analysis of the current situation, with their parallels in the 1960s. The first strand puts the blame squarely on the subordination of US economic policies to domestic objectives, at the expense of external adjustment. In the 1960s, many argued, the US was unwilling to pursue the tight monetary policy that would have been required to prevent the drain on gold reserves. Instead, the US adopted indirect policy initiatives (interest equalization tax, offset 'agreements', import surcharge) that were designed specifically to free monetary policy from its external constraint. In the current context, this line of thought emphasizes the impact of the recent string of fiscal deficits (Bush tax cuts, military expenditures) on national savings (Roubini and Setser (2004))

Seen in the broader perspective that our data analysis allows, it is not clear that this can be the whole story. Since 1973, and the decoupling of the US dollar from gold, the dollar exchange rates has been largely free to adjust and restore external stability -if need be- through the usual channels of adjustment. Yet, what do we observe since 1973? First, a stabilization, even an improvement between 1975 and 1980, where the ratio of net assets to GDP climbs back to its 1960s level (10 percent). But this is followed by an unprecedented slide between 1980 and 2004, from 10 percent to -26 percent of GDP. Looking at the figure, the Bretton Woods era looks like a period of relatively modest balance of payments imbalances. ${ }^{17}$ While domestic fiscal and monetary developments certainly play a role, we are struck by the secular decline in net foreign assets across the Reagan combination of fiscal deficits and tight money, the Clinton era of fiscal rectitude and surging asset prices, to the current descent into fiscal deficits and lax monetary policy.

\footnotetext{
${ }^{17}$ This is in part due to the fact that the external constraint manifested itself on a small subset of the overall external balance sheet of the US, the Official Settlement Balance. The US experienced a gold drain even though it was running small current account surpluses over that period. But the larger point that the overall external portfolio of the US did not deteriorate much over that period is still valid.
} 
A second line of thought emphasized the unique role of the US as the provider of the main international currency and liquidity. In 1966, Despres et al. argued that the US was the world banker. It provided safe low yield assets to world savers with a preference for liquidity. In exchange, US investors, with a lower taste for liquidity, saw investment opportunities in the rest of the world in the form of long term loans. This line of thought has two modern incarnations. The first variation puts the emphasis on the central banks of developing countries and their incentive to subsidize US consumption by accumulating US treasury bills (Dooley et al. (2003)). The second variation is very much in the spirit of the original Despres et al. (1966) analysis. It sees the US as a provider of safe financial assets to the rest of the world (Bernanke (2005), Cooper (2004)). Following the Asian and Russian crisis, the high savings from emerging economies looked for a safe and liquid haven. US assets, especially treasuries, provided the perfect vehicle. As we show, there is substantial evidence that the US does indeed perform the functions of a liquidity provider. This is perhaps even more the case since the liberalization of financial markets that allow equity and direct investment in emerging economies. From world banker, the US has become, for all intents and purposes, the world venture capitalist!

Yet, that analysis does not imply that the current situation can be maintained indefinitely. In fact, our analysis of the tipping point indicates that while the US is still some ways away from making net payments on its mounting stock of net liabilities, that moment is approaching. Foreign lenders could decide to stop financing the US external deficit and run away from the dollar, either in favor of another currency such as the Euro, or just as dramatically, require a risk premium on US liquid assets whose safety could not be guaranteed any longer. In either case, the repercussions could be quite severe, with a decline in the value of the dollar, higher domestic interest rates and yields, and a global recession.

The previous discussion points to a possible instability, even in an international monetary system that lacks a formal anchor. The relevant reference here is Triffin's prescient work on the fundamental instability of the Bretton Woods system (see Triffin (1960)). Triffin saw that in a world where the fluctuations in gold supply were dictated by the vagaries of discoveries in South Africa or the destabilizing schemes of Soviet Russia, but in any case unable to grow with world demand for liquidity, the demand for the dollar was bound to eventually exceed the gold reserves of the Federal 
Reserve. This left the door open for a run on the dollar. Interestingly, the current situation can be seen in a similar light: in a world where the US can supply the international currency at will, and invests it in illiquid assets, it still faces a confidence risk. There could be a run on the dollar not because investors would fear an abandonment of the gold parity, as in the seventies, but because they would fear a plunge in the dollar exchange rate. In other words, Triffin's analysis does not have to rely on the gold-dollar parity to be relevant. Gold or not, the specter of the Triffin dilemma may still be haunting us! 


\section{References}

Bernanke, Ben, "The Global Saving Glut and the U.S. Current Account Deficit," Sandridge Lecture, Virginia Association of Economics, Richmond, Virginia, Federal Reserve Board March 2005.

Blanchard, Oliver, Francesco Giavazzi, and Filipa Sa, "The U.S. Current Account and the Dollar," NBER Working Papers 11137, National Bureau of Economic Research, February 2005.

Campbell, John, "Asset Prices, Consumption, and the Business Cycle," in John B. Taylor and Michael Woodford, eds., Handbook of Macroeconomics, North Holland Elsevier Amsterdam 1999.

_, Andrew Lo, and A. Craig MacKinlay, The Econometrics of Financial Markets, Princeton NJ: Princeton University Press, 1997.

Cooper, Richard N., "US deficit: It is not only sustainable, it is logical," Financial Times, October 312004.

Despres, Emile, Charles Kindleberger, and Walter Salant, "The Dollar and World Liquidity: A Minority View," The Economist, February 5 1966, 218 (5).

Dooley, Michael P., David Folkerts-Landau, and Peter Garber, "An Essay on the Revived Bretton Woods System," NBER Working Paper 9971, National Bureau of Economic Research September 2003.

Eichengreen, Barry, "Global Imbalances and the Lessons from Bretton Woods," NBER Working Paper 10497, National Bureau of Economic Research May 2004.

Federal-Reserve-Board, Guide to the Flow of Funds Accounts, Washington, D.C.: Board of Governors of the Federal Reserve System, 2000.

Gourinchas, Pierre-Olivier and Hélène Rey, "International Financial Adjustment," NBER Working Paper 11155, National Bureau of Economic Research February 2005.

Hooker, Sarah A. and John F. Wilson, "A Reconciliation of Flow of Funds and Commerce Department Statistics on U.S. International Transactions and Foreign Investment Position," July 1989. unpublished, Board of Governors of the Federal Reserve System.

International-Monetary-Fund, Balance of Payments Manual, 5th Edition, Washington DC: International Monetary Fund, 1993.

Kindleberger, Charles, "Balance of Payments Deficits and the International Market for Liquidity," Essays in International Finance, May 1965, 46.

Lane, Philip R. and Gian Maria Milesi-Ferretti, "The External Wealth of Nations: Measures of Foreign Assets and Liabilities for Industrial and Developing Countries," Journal of International Economics, December 2001, 55, 263-94. and __, "Financial Globalization and Exchange Rates," mimeo, International Monetary Fund $\overline{2004}$. and _ _ "A Global Perspective on External Positions," mimeo: International Monetary Fund june 2005 .

McCulloch, J. Huston and Heon-Chul Kwon, "U.S. Term Structure Data, 1947-1991," working paper 93-6, www.econ.ohio-state.edu/jhm/ts/mcckwon/mccull.htm, Ohio State University 1993.

Obstfeld, Maurice and Alan Taylor, "Sources of America's 'Exorbitant Privilege," in progress 2005. mimeo: University of California. and Kenneth Rogoff, "The Unsustainable US Current Account Position Revisited," NBER Working Paper 10869, National Bureau of Economic Research, Inc November 2004.

Portes, Richard and Hélène Rey, "The Emergence of the Euro as an International Currency," Economic Policy, April 1998, pp. 305-343. 
Roubini, Nouriel and Brad Setser, "The US as a Net Debtor: The Sustainability of the US External Imbalances," mimeo, NYU November 2004.

Tille, Cedric, "The Impact of Exchange Rate Movements on U.S. Foreign Debt," Current Issues in Economics and Finance, 2003, 9 (1), 1-7.

, "Financial Integration and the Wealth Effect of Exchange Rate Fluctuations.," mimeo, Federal Reserve Bank of New York 2004.

Triffin, Robert, Gold and the dollar crisis; the future of convertibility, New Haven: Yale University Press, 1960.

US Treasury, "U.S. Holdings of Foreign Long-Term Securities as of December 1997 and December 1999," 2000. Department of the Treasury. Division of International Finance, Board of Governors of the Federal Reserve System. www.ustreas.gov/fpis/.

, "Survey of Foreign Portfolio Holdings of U.S. Securities, as of June 2002," 2002. Department of the Treasury. Division of International Finance, Board of Governors of the Federal Reserve System.

_ , "U.S. Holdings of Foreign Long-Term Securities as of December 2001," 2003. Department of the Treasury. Division of International Finance, Board of Governors of the Federal Reserve System. www.ustreas.gov/fpis/. 


\section{Appendix A \\ Detailed Description of the Construction of the International Investment Position for the U.S.}

\section{A.1 Overview of Data Issues and Methodology}

In order to evaluate the extent and the nature of US external imbalances, one needs an accurate measure of the international investment position (IIP) of the US. A major drawback of the official balance of payments statistics is the absence of valuation in the current account measures. This implies that if one were to simply cumulate the current account to compute the net foreign asset position of the United States, one would get a biased estimate.

Data on the net and gross foreign asset position of the U.S. is available from two sources: the U.S. Department of Commerce's Bureau of Economic Analysis (BEA) and the Federal Reserve Flows of Funds Accounts (FFA) for the rest of the world. The BEA reports annually its International Investment Position of the United States. The IIP details gross and net foreign asset positions at the end of the year since 1976. In addition, the BEA reports quarterly flow data in the US International Transactions (USIT) tables since 1960 for some flow series, 1982 for others. ${ }^{18}$ The BEA data uses Balance of Payment concepts, in accordance with the IMF's Manual of the Balance of Payments (1993). Following official classifications, we split U.S. net foreign portfolio into four categories: Debt (corporate and government bonds), Equity, Foreign Direct Investment (FDI) and Other. The 'other' category includes mostly bank loans and trade credits. The BEA data provide equity and FDI (since 1980) figures at market value and perform an exchange rate adjustment for debt. The quality of the data is good. ${ }^{19}$

For its part, the Federal Reserve publishes since 1952 the quarterly flows and positions for the "rest of the world" account, as part of its Flow of Funds accounts. While covering a longer sample, the FFA data presents two drawbacks. First, equity positions are the only series recorded at market value. Debt, FDI and 'Other' claims and liabilities are recorded at historical costs. Second, the FFA data is of poorer quality and uses National Income and Product Account (NIPA) concepts that differ subtly from their BoP equivalent. But the primary source data are often similar, except for a few items such: ${ }^{20}$ (i) the treatment of international banking facilities (IBF) and (ii) the treatment of the Netherlands Antilles Affiliates. An IBF is a set of "books" maintained by a US bank that are not subject to domestic banking regulations. They allow US banks to offer offshore banking services "onshore". The BEA considers that IBF are "inside" the US while the FFA consider that they are foreign residents. As to the second point, the BEA treats all transactions between parents and affiliates as part of Direct Investment. Instead, the FFA treats these flows as part of corporate debt liabilities.

Our approach was to supplement the BEA's IIP data for all categories of assets and liabilities, and each point in time back to 1952, using Survey of Current Business reported holdings for Equity and Debt, BEA and FFA flow data, US Treasury benchmark surveys on holdings, and by constructing valuation adjustments for each subcategories of assets and liabilities. In this appendix, we describe in detail our methodology for constructing the gross asset and liability positions of the US on a quarterly basis since 1952. In particular we provide a reconciliation of the data treatment of the Flow of Funds and the BEA.

Denote $P X_{t}$ the end of period $t$ position for some asset category $X$. We use the following updating equation:

$$
P X_{t}=P X_{t-1}+F X_{t}+D X_{t}
$$

\footnotetext{
${ }^{18}$ For instance, equity and debt flows are available separately after 1982 only.

${ }^{19}$ Technically, the BEA provides data on FDI at market value since 1982. However, the IMF constructed market value positions for 1980 and 1981. We use these estimates in our analysis.

The Lane and Milesi-Ferretti (2001) data set includes annual data since 1973 and coincides with the BEA data after 1980.

${ }^{20}$ See Hooker and Wilson (1989) for a detailed comparison.
} 
where $F X_{t}$ denotes the flows corresponding to asset $X$ that enters the balance of payments, and $D X_{t}$ denotes a discrepancy reflecting a market valuation adjustment between periods $t-1$ and $t$. When we cannot measure $D X_{t}$ directly, we construct an estimate as $r_{t}^{x} P X_{t-1}$ where $r_{t}^{x}$ represents the estimated dollar capital gain on category $X$ between time $t-1$ and time $t$. Our approach therefore requires that we specify market returns $r_{t}^{x}$ for each sub-category of the Financial Account.

Data in the final quarter of each year are mapped to the International Investment Position (IIP) data of the BEA, when available. ${ }^{21}$ Therefore, the valuation term between the third and fourth quarters includes all adjustments not captured by our valuation method, such as change in the coverage of the series.

\section{A.2 Reconciliation of the Flow of Funds and the BEA data.}

\section{A.2.1 Mapping the flows}

The material in this section draws heavily from Hooker and Wilson (1989). It is important to understand why and how the FFA and BEA data differ. First and foremost, one should realize that the BEA and FFA data are essentially compiled from the same source data. The main differences lie in the definition of the various concepts (NIPA vs BoP), their geographical coverage, and the treatment of valuation effects. This appendix clarifies the points relevant to our analysis.

To establish a correspondence between FFA and BEA, we start from the Balance of Payment's identity:

$$
C A+K A+F A+S D=0
$$

where $C A$ denotes the U.S. current account (USIT Table 1 line 76 ), $K A$ the U.S. capital account (Table 1 line 39), $F A$ denotes the financial account (Table 1 line 40 and 55) and $S D$ the statistical discrepancy (errors and omissions, Table 1 line 70$).{ }^{22}$

The equivalent accounting identity in the FFA takes the following form: ${ }^{23}$

$$
C A^{\prime}+K A^{\prime}+F A^{\prime}+S D^{\prime}=0
$$

where $C A^{\prime}$ denotes the NIPA's current account (FFA Table F107 line 5 minus line 1 ), $K A^{\prime}$ is the (NIPA) net capital transfers (Table F107 line 8 with sign reversed), $F A^{\prime}$ denotes NIPA's Net Financial Investment (Table F107 line 12) and $S D^{\prime}$ denotes the (NIPA) statistical discrepancy (Table F107 line 55). $K A^{\prime}$ is equal to $K A$, so that we can combine (A.2) and (A.3) to obtain:

$$
S D^{\prime}=\left(C A-C A^{\prime}\right)+\left(F A-F A^{\prime}\right)+S D
$$

The NIPA statistical discrepancy $S D^{\prime}$ is equal to the BoP statistical discrepancy $S D$ plus an adjustment for the difference in the definitions of the current and financial accounts in the NIPA and BoP respectively.

Next, we decompose the financial accounts $F A^{\prime}$ and $F A$ as follows:

$$
\begin{aligned}
F A^{\prime} & =F A_{f}^{\prime}-F A_{u s}^{\prime} \\
F A & =F A_{f}+F A_{u s}
\end{aligned}
$$

where $F A_{f}^{\prime}$ (resp. $F A_{f}$ ) represents the change in foreign-owned U.S. assets (gross liabilities) in the FFA (resp. the $\mathrm{BoP}$ ) and $F A_{u s}^{\prime}$ (resp $F A_{u s}$ ) represents the change in U.S.-owned assets abroad (gross assets) in

\footnotetext{
${ }^{21}$ The only exception is for Direct Investment. The reason is that when we extend the valuation adjustment used by the BEA before 1980, we end up with negative gross positions before 1970. This could come from an imperfect accounting of reinvested earnings. According to the Balance of Payments manual, direct investment income in the current account includes distributed earnings as well as the share of reinvested earnings with an offsetting entry in the financial account. This implies that reinvested earnings are included in the flow $F X_{t}$ and should be excluded from the return $r_{t}^{x}$ in equation (A.1). We adjusted the valuation terms to replicate the BEA's annual adjustment from 1982 onward but chose to start both FDI gross asset and liabilities position at 0 at the beginning of our sample and update (A.1) forward.

${ }^{22}$ All line references in USIT Table 1 and FFA Table F107 are accurate as of January 2005.

${ }^{23}$ Note that we write this equation from the point of view of the U.S., while the FFA is from the perspective of the rest of the world. So $C A^{\prime}$ is the opposite of the current account recorded in the FFA.
} 
the FFA (resp. the BoP). ${ }^{24}$ The Guide to the Flows of Funds (2000) (pp370-380) establishes the following correspondence between $F A_{f}^{\prime}$ and $F A_{f}$ :

$$
\begin{aligned}
F A_{f}^{\prime}= & F A_{f}+\text { Gold and SDR (F107 line 14) } \\
& + \text { net issuance of bonds by Netherland Antillean subsidiaries (F107 line 27b) } \\
& \text { - change in interbank claims on foreigners (F107 lines 15f to 15l) }
\end{aligned}
$$

Accordingly, gross external liabilities according to the BEA and the FFA exhibit three differences:

1. The FFA treats transactions involving Gold and SDR as changes in foreign assets, while the BEA treats them as changes in U.S. assets. In the FFA, Gold and SDR (F107 line 14) corresponds to sales of Gold and SDR by the U.S. (USIT Table 1 lines 42 and 43), with the sign reversed.

2. In the late 1970s and 1980s, some U.S. corporations established financial subsidiaries in the Netherland Antilles to tap international capital markets and avoid capital control and tax laws. The subsidiary would issue Eurobonds and channel the funds back to the U.S. parent company. The Balance of Payments considers all transactions between parent and affiliates as part of Direct Investment and subtracts issuance of eurobonds by foreign financial subsidiaries from direct investment outflows. By contrast, the FFA treats these capital flows as direct bond issuance by the U.S parent companies, adds them to bond liabilities and adds them back to foreign direct investment outflows. ${ }^{25}$ The removal of the withholding tax in 1984 eliminated the incentive to use overseas subsidiaries to issue Eurobonds. The FFA practice was discontinued in 1992Q4.

3. The FFA nets interbank claims while the BEA reports claims on a gross basis. ${ }^{26}$ In order to map back the FFA to the BEA, we need to subtract the "changes in net interbank claims on foreigners" (lines 15 f to 151$)$.

Further, $F A_{u s}^{\prime}$ must satisfy the key identity (A.3), given $S D^{\prime}$ :

$$
F A_{u s}^{\prime}=F A_{f}^{\prime}+C A^{\prime}+K A^{\prime}+S D^{\prime}
$$

The last piece of the puzzle is the definition of $S D^{\prime}$ in the FFA given by:

$$
\begin{aligned}
S D^{\prime}(\mathrm{F} 107 \text { line } 55)= & \left.-C A^{\prime}-K A^{\prime} \text { (F107 line } 8 \text { with minus sign }\right) \\
& +S D(\text { F107 line } 55 \mathrm{a}) \\
& +C A(\text { F107 line } 55 \mathrm{~b} \text { with opposite sign })
\end{aligned}
$$

Combining with equation (A.4), we obtain:

$$
F A^{\prime}=F A+K A
$$

In words, the FFA net investment position includes the BEA capital transfers.

Combining (A.7) and (A.6), we extract $F A_{u s}^{\prime}$ as:

$$
\begin{aligned}
F A_{u s}^{\prime}= & -F A_{u s}-K A \\
& + \text { Gold and SDR (F107 line 14) } \\
& + \text { Net issuance of bonds by Net. Ant. subsidiaries (F107 line 27b) } \\
& \text { - change in interbank claims on foreigners (F107 lines 15f to 15l) }
\end{aligned}
$$

\footnotetext{
${ }^{24}$ with the BoP convention that $F A_{u s}<0$ when there is a gross capital outflow.

${ }^{25}$ This assumes that the bond issue is purchased entirely by the rest of the world.

${ }^{26}$ Net interbank claims (F107 line 15) = interbank liabilities (F107 lines 15a-e) - interbank claims (F107 lines $\left.15 \mathrm{f}-\mathrm{l}\right)$. An additional distinction comes from the treatment of International Banking Facilities, counted as domestic entities in the BoP and foreign entities in the FFA. We lump this term with the change in interbank claims on foreigners.
} 
To summarize, the asset flow side has the same adjustments as the flow liability side, plus the subtraction of the capital account transactions.

In order to construct a measure of the U.S. international investment position comparable with existing measures, we adopt the BEA's classification. Accordingly, we adopt the following decomposition for gross assets and liabilities:

$$
F A_{f}=F E L+F D L+F F L+F O L
$$

with:

$$
\begin{aligned}
F A_{f} & =\text { Foreign-owned assets in the US (Table } 1 \text { line } 55) \\
F E L & =\text { Equity (Table 7a line } \mathrm{B} 4 \text { and memo line } 4) \\
F D L & =\text { Debt (Table } 7 \mathrm{a} \text { line } 16,30 \text { and memo line } 3 \text { ) } \\
F F L & =\text { Direct investment (Table } 1 \text { line } 64)
\end{aligned}
$$

and

$$
-F A_{u s}=F E A+F D A+F F A+F O A
$$

with

$$
\begin{aligned}
F A_{u s} & =\text { U.S.-owned assets abroad, Table } 1 \text { line } 40 \\
F E A & =\text { Equity (Table } 7 \text { a line A4) } \\
F D A & =\text { Debt (Table } 7 \text { a line } 18) \\
F F A & =\text { Direct investment (Table } 1 \text { line } 51)
\end{aligned}
$$

We have similar definitions for the FFA based gross flows:

$$
F A_{f}^{\prime}=F E L^{\prime}+F D L^{\prime}+F F L^{\prime}+F O L^{\prime}
$$

with

$$
\begin{aligned}
F A_{f}^{\prime} & =\text { Net acquisition of financial assets (Table F107 line 13) } \\
F E L^{\prime} & =\text { Equity (Table F107 line 29) } \\
F D L^{\prime} & =\text { Debt (Table F107 line 21, } 24 \text { and } 27) \\
F F L^{\prime} & =\text { Direct investment (Table F107 line 33) }
\end{aligned}
$$

as well as for $F A_{u s}^{\prime}$ :

$$
F A_{u s}^{\prime}=F E A^{\prime}+F D A^{\prime}+F F A^{\prime}+F O A^{\prime}
$$

with

$F A_{u s}^{\prime}=$ Net increase in liabilities of the rest of the world (Table 107 line 35)

$F E A^{\prime}=$ Equity (Table 107 line 47)

$F D A^{\prime}=$ Debt (Table 107 line 40)

$F F A^{\prime}=$ Direct investment (Table 107 line 53) 
According to the Guide to the Flow of Funds (2000), the FFA and BoP series satisfy:

$$
\begin{aligned}
F D L^{\prime}= & F D L \\
& + \text { net issuance of bonds by Net. Ant. subsidiaries (F107 line 27b) } \\
F E L^{\prime}= & F E L \\
F F L^{\prime}= & F F L \\
F E A^{\prime}= & F E A \\
F D A^{\prime}= & F D A \\
F F A^{\prime}= & F F A \\
& + \text { net issuance of bonds by Net. Ant. subsidiaries (F107 line 27b) }
\end{aligned}
$$

from which we conclude that:

$$
\begin{aligned}
F O L^{\prime}= & F O L+\text { Gold and SDR (F107 line 14) } \\
& - \text { change in interbank claims on foreigners (F107 lines 15f to 15l) } \\
F O A^{\prime}= & F O A-K A \\
& + \text { Gold and SDR (F107 line 14) } \\
& - \text { change in interbank claims on foreigners (F107 lines 15f-15l) }
\end{aligned}
$$

Appendix B presents a line by line description of the mapping.

\section{A.2.2 The Dynamics of the External Budget Constraint.}

The stock data in the BEA is updated as follows:

$$
P X_{t+1}^{i}=P X_{t}^{i}+F X_{t+1}^{i}+D X_{t+1}^{i}
$$

where $P X_{t}^{i}$ represents the position at the end of period $t$ for series $i, F X_{t}^{i}$ the flow during period (BEA definition) $t$ and $D X_{t}^{i}$ a discontinuity reflecting a market valuation adjustment or a change of coverage in the series between $t-1$ and $t$. Summing across all the series, we obtain the international investment position at the end of period $t+1$ :

$$
\begin{aligned}
N F A_{t+1} & =\sum_{j} P A_{t+1}^{j}-\sum_{i} P L_{t+1}^{i} \\
& =\sum_{j}\left(P A_{t}^{j}-F A_{t+1}^{j}+D A_{t+1}^{j}\right)-\sum_{i}\left(P L_{t}^{i}+F L_{t+1}^{i}+D L_{t+1}^{i}\right) \\
& =N F A_{t}-\left(\sum_{j} F A_{t+1}^{j}+\sum_{i} F L_{t+1}^{i}\right)+\left(\sum_{j} D A_{t+1}^{j}-\sum_{i} D L_{t+1}^{i}\right)
\end{aligned}
$$

In turn, the flow data satisfies:

$$
\begin{aligned}
-F A_{t} & =-\sum_{j} F A_{t}^{j}-\sum_{i} F L_{t}^{i} \\
& =C A_{t}+S D_{t}+K A_{t}
\end{aligned}
$$

where we used the fundamental BoP equation. Substituting,

$$
N F A_{t+1}=N F A_{t}+C A_{t+1}+S D_{t+1}+K A_{t+1}+N D_{t+1}
$$


where

$$
N D_{t}=\sum_{j} D A_{t}^{j}-\sum_{i} D L_{t}^{i}
$$

is the net discrepancy. In the case where there is no change in coverage of the data, this net discrepancy corresponds to the capital gains. Further, we can write the current account as follows:

$$
C A_{t}=N X_{t}+I_{t}+U T_{t}
$$

where $I_{t}$ denotes net income receipts (including interest income, distributed dividends and FDI earnings) , and $U T_{t}$ represents unilateral transfers plus net compensation of employees. ${ }^{27}$ The sum of $I_{t+1}$ and $N D_{t+1}$ represents the total return on the net foreign asset portfolio between $t$ and $t+1,\left(R_{t+1}-1\right) N F A_{t}$. We can then rewrite the accumulation equation as:

$$
N F A_{t+1}=R_{t+1} N F A_{t}+N X_{t+1}+U T_{t+1}+K A_{t+1}+S D_{t+1}
$$

\section{Appendix B \\ Line by Line Description, Flows, Positions and Return Data.}

The remainder of this appendix presents a line by line account of the construction of the US international investment position of the US, from 1952:1 to 2004:1.

List of acronyms:

BEA Bureau of Economic Analysis (Department of Commerce)

FFA Flow of Funds (Federal Reserve)

USIT U.S. International Transactions, BEA, BoP concepts

IIP U.S. International Investment Position, BEA, BoP concepts

SCB Survey of Current Business, published by BEA

\section{B.1 Assets.}

- Equity:

- flows:

* After 1982Q1 from BEA (USIT Table 7b line A2 before 1998Q1 then USIT Table 7a line A4).

* Before 1982, from FFA, table F107 line 47 (FU263164003.Q, foreign corporate equities, including ADRs, NSA). Before 1974Q1, the FFA series reports incorrectly the sum of equity and debt holdings by US residents (also reported in USIT Table 1 line 52). The flow series is corrected by subtracting FFA table F107 line 40 (FU263163003.Q, bonds, NSA). This error is corrected in the FFA data published after June 2004.

- levels: End of year positions from BEA.

* After 1976, BEA IIP Table 2 line 21 (corporate stocks, including results from the U.S. Treasury's 1994 and 1997 Benchmark Surveys of U.S. Ownership of Foreign Long-term Securities).

* Before 1976, SCB, various lines.

- valuation adjustment: Quarterly equity portfolio dollar capital gains constructed using the U.S. Treasury 1997 Benchmark Surveys of U.S. Ownership of Foreign Long-term Securities (Series EQR97\$). Details on returns provided in section B.3.

\footnotetext{
${ }^{27}$ According to the BOP manual, direct investment income in the CA includes distributed earnings as well as the share of reinvested earnings. So there is an entry in the current account and an offsetting entry in the financial account.
} 


\section{- Debt:}

- flows:

* After 1982Q1, from BEA (USIT Table 7b line A13 before 1998Q1, then USIT Table 7a line A18).

* Before 1982, from FFA, Table F107 line 40 (FU263163003.Q, Bonds, NSA).

- levels: end of year positions from BEA.

* After 1976, positions from BEA IIP Table 2 line 20 (Bonds, including results from the U.S. Treasury's 1994 and 1997 Benchmark Surveys of U.S. Ownership of Foreign Long-term Securities).

* Before 1976, positions available from SCB.

- valuation adjustment: Maturity Weights: $25 \%$ short term, $75 \%$ long term. No valuation adjustment for short term. For long term bonds, weighted average dollar holding period excess return (over yields) (series RN\$@W). Details on returns provided in section B.3.

\section{- Direct Investment:}

- flows:

* After 1960Q1 from BEA (USIT Table 1 Line 51).

* Before 1960Q1, from FFA Table F107 line 53 (FU263192005.Q, U.S. direct investment abroad). Note that through 1992Q4, FFA US direct investment abroad excludes net inflows from corporate bonds issued by Netherlands Antillean financial subsidiaries. There is no discrepancy here since these bonds issues start after 1978.

- levels: Start positions at 0 in 1952Q1 and cumulate forward. Note that we do not benchmark the data to the BEA IIP series (Table 2 line 18) available after 1982 at market value. The reason is that applying the BEA valuation adjustment backwards from 1982Q4 results in negative gross FDI asset position before 1973. Our estimated position for 1982Q4 is $\$ 267 \mathrm{bn}$. The BEA reports $\$ 227$ bn.

- valuation adjustment: Quarterly direct investment portfolio capital gains constructed using rolling weights (series RFDR $\$$ ). The weights are constructed using BEA direct investment positions by country (historical cost basis) from 1966 until 2002. The final shares cover $75 \%$ of DI assets in each year. The implicit annual return in the BEA positions is regressed on this capital gain series between 1982 and 2003. The regression coefficient (0.754367) is used to scale down the capital gain series. It is smaller than one, as expected. The reason is that the BEA records reinvested earnings as inflows. But reinvested earnings are also part of the capital gain series. Without adjustment, we would be double-counting the reinvested earnings.

\section{- Other Assets:}

- flows:

* Before 1960Q1, other asset flows are constructed to match the BEA definition. We start with other asset flows defined from FFA: FFA total assets (Table F107 line 35, FU264190005.Q, Net increase in U.S. liabilities of the rest of the world) minus FFA bonds (F107 line 40, FU263163003.Q, change in bond liabilities of the rest of the world to U.S. residents) minus FFA equity (F107 line 47, FU263164003.Q, Net purchase of foreign corporate equities by U.S. residents) [corrected, see the description of equity asset flows] minus FFA direct investment (F107 line 53, FU263192005.Q, U.S. direct investment abroad, excluding bonds sold by Netherlands Antillean financial subsidiaries). Then, we adjusts the flows to map into the BEA definitions: Other assets from FFA plus capital account (USIT Table 1 line 39) plus change in interbank claims.

* After 1960Q1, defined as residual from total BEA asset flows: total assets (USIT Table 1 line 40, U.S. owned assets abroad) minus Equity, Debt and Direct Investment flows. 
- levels: After 1976, end of year positions from BEA IIP Table 2 line 5 (U.S. official reserve assets) plus line 10 ( U.S. Government assets, other than official reserve assets) plus line 22 ( U.S. claims on unaffiliated foreigners reported by U.S. nonbanking concerns) and line 23 ( U.S. claims reported by U.S. banks, not included elsewhere). Note that the levels and the flows include Gold Reserves.

- valuation adjustment: none.

\section{B.2 Liabilities}

- Equity:

- flows:

* After 1973Q1, sum of BEA equity (SCB before 1982Q1, USIT Table 7b line B2 between 1982Q1 and 1998Q1 then Table 7a line B4 after) and Equity held by foreign officials (SCB before 1982Q1, USIT Table 7b line memo 4 between 1982Q1 and 1998Q1 and Table 7a line memo 4 after).

* Before 1973, FFA equity Table F10 7 line 29 (FU263064003.Q, Net purchases of U.S. corporate equity by the rest of the world). The FFA data includes equity purchased by foreign official agencies (reported separately by the BEA).

- levels: End of year positions from BEA.

* After 1980, positions from IMF IIP (B8660@C111). The IMF data includes equity holdings by foreign official agencies.

* Between 1976 and 1980, comparison of the BEA IIP Table 40 (corporate stocks) show that foreign official holdings are 0 .

* Before 1976, positions available from Survey of Current Business.

- valuation: quarterly equity portfolio capital gains (series EQRUS) from S\&P 500 (see detailed descriptions for returns in section B.3).

- Debt:

- flows:

* After 1982Q1, from BEA flows. Sum of private foreign holdings of US corporate and federally sponsored agency bonds (USIT Table 7b line 10 before 1998, then Table 7a line 16 and 30) and foreign official holdings of U.S. government securities (USIT Table 1 line 57) and foreign private holdings of U.S. Treasury securities (USIT Table 1 line 65) and corporate and agency bonds held by foreign official agencies (USIT Table 7b line memo 3 before 1998, then Table 7a memo 3).

* Before 1982,FFA U.S. treasury securities (Table F107.21, FU263061105.Q, treasury securities) plus U.S. agency and GSE-backed securities (Table F107.24, FU263061705) plus U.S. corporate bonds (Table F107.27, FU263063005.Q, includes net issues by Netherland Antillean financial subsidiaries of U.S. corporations) minus estimate of net issues of corporate bonds from Netherland Antillean financial subsidiaries of U.S. corporations. Each FFA series is constructed/corrected as follows:

- FFA Table F107 line 22 (FU263061113.Q, foreign official holdings of Treasury securities), a subcategory of F107 line 21, is incorrect before 1981Q4. The series is remapped to BEA Table 1 line 58 (foreign official holdings of U.S. Treasury securities).

- FFA Table F107 line 27 adjusted upwards before 1977Q3 for discontinuity in the coverage of the series (see section C.2 for a methodological description on how we treat discontinuities in coverage).

- Net issues of corporate bonds from Netherland Antillean financial subsidiaries estimated as the difference between minus FFA-based direct investment assets (Table F107 line 53, FU263192005.Q, U.S. direct investment abroad) and BEA-based direct investment assets (USIT Table 1 line 51). Set to 0 before 1979Q1. 
- levels:

* After 1982, end of year positions from IMF IIP (B8669@C111). The IMF data includes foreign official agencies holdings of corporate bonds (reported separately in BEA IIP).

* Between 1976 and 1981, from BEA IIP (Table 2) line 27 (foreign official holdings of U.S. government securities) plus line 37 (foreign private holdings of U.S. Treasuries) plus line 39 (foreign private holdings of corporate and other bonds) plus line 32 (foreign official holdings of other assets).

* Between 1971 and 1976, same positions available from Survey of Current Business. No data available before 1971 .

- valuation: we assume a maturity structure of $25 \%$ short term (no valuation) and $75 \%$ long term. For the long term valuation, we use the quarterly holding excess return over yields on 10-year U.S. government debt (series RN@C111), see section B.3.

\section{- Direct Investment:}

- flows:

* After 1976Q4, from BEA direct investment (USIT Table 1 line 64). The FFA series (Table F107 line 33, FU263092001.Q, foreign direct investment in the U.S.) is identical to the BEA series after 1960 .

* Before 1976Q4, FFA series (Table F107 line 33, FU263092001.Q, foreign direct investment in the U.S.), adjusted upwards for the discontinuity in coverage in 1976Q4 (see section C.2 for a methodological description on how we treat discontinuities in coverage).

- levels: Start positions at 0 in 1952Q1 and cumulate forward. Note that we do not benchmark the data to the BEA IIP series (Table 2 line 36) available after 1982 at market value. The reason is that applying the BEA valuation adjustment backwards from 1982Q4 results in negative gross FDI liability position before 1973. Our estimated position for 1982Q4 is $\$ 144 \mathrm{bn}$. The BEA reports $\$ 130$ bn.

- valuation: Quarterly direct investment portfolio capital gains constructed using S\&P 500 capital gains series (EQRUS). The implicit annual return in the BEA positions from 1982 to 2003 is regressed on this capital gain series. The regression coefficient (0.681023) is used to scale down the capital gain series. It is smaller than one, as expected. The reason is that the BEA records reinvested earnings as inflows. But reinvested earnings are also part of the capital gain series. Without adjustment, we double-count reinvested earnings.

\section{- Other liabilities:}

- flows:

* After 1976Q4, defined as residual from total BEA liabilities: total liabilities (USIT Table 1 line 55) minus Debt, Equity and Direct Investment liability flows.

* Between 1960Q1 and 1976Q3, defined as residual from total BEA liabilities: total liabilities (USIT Table 1 line 55) minus Debt, Equity and Direct Investment liability flows measured as USIT Table 1 line 64. [Note: the DI flows are not adjusted upward for the discontinuity. Hence, we are assuming that total liabilities are mismeasured before 1976Q4].

* Before 1960Q1, constructed from FFA to match the BEA definition (see A.2). Start with Other Liabilities FFA flows defined as FFA total liabilities (Table F107 line 13, FU264090005.Q, Net acquisition of financial assets by the rest of the world) minus FFA bonds (F107 line 21 FU263061105, Treasury Securities, F107 line 24, FU263061705, Agency and GSE backed securities, F107 line 27, FU263063005 U.S. corporate bonds, all series corrected as described above), minus FFA equity (F107 line 29, FU263064003.Q) minus FFA direct investment (F107 line 33, FU263092001.Q). Then adjust FFA series to map into the BEA definition: Other Liability (FFA) minus FFA Gold and SDR (F107 line 14, FU263011005.Q, net purchases of Gold and SDR from the U.S. by the rest of the world) plus change in interbank claims (equal to zero before 1960). 


\begin{tabular}{lcccl}
\hline country & $1952-1966$ & $1966-1987$ & $1987-2004$ & series \\
\hline UK & 27.43 & 25.44 & 23.61 & FT-Actuaries All-Share Total Return Index \\
Japan & 17.20 & 15.95 & 14.80 & Nikko Securities Composite Total Return \\
France & 10.72 & 9.94 & 9.23 & SBF-250 Total Return Index \\
Netherlands & 13.49 & 12.51 & 11.61 & CBS Total Return-All Shares \\
Germany & 8.19 & 7.60 & 7.05 & CDAX Total Return Index \\
Canada & 8.93 & 8.28 & 7.68 & Toronto SE-300 Total Return Index \\
Sweden & 4.89 & 4.54 & 4.21 & Stockholm SBX Benchmark Gross Index. \\
Switzerland & 0.00 & 7.24 & 6.72 & Performance Index. \\
Italy & 5.24 & 4.86 & 4.51 & BCI Global Return Index \\
Mexico & 0.00 & 0.00 & 3.79 & SE Return Index \\
Australia & 3.92 & 3.64 & 3.38 & S\&P/ASX 200 Accumulation Index. \\
Brazil & 0.00 & 0.00 & 3.4 & Sao Paulo IBX-50 Return Index. \\
\hline
\end{tabular}

Table 5: Country-Weights, Equity Assets, Total Returns.

- levels: After 1976, end of year positions from BEA IIP. Table 2 line 30 ( Other U.S. Government liabilities) and line 31 (U.S. liabilities reported by U.S. banks, not included elsewhere) and line 41 (U.S. currency) and line 42 (U.S. liabilities to unaffiliated foreigners reported by U.S. nonbanking concerns) and line 43 (U.S. liabilities reported by U.S. banks, not included elsewhere).

- valuation: none.

\section{B.3 Returns}

Most financial and exchange rate data are obtained from the Global Financial Database (GFD) and International Financial Statistics (IFS).

\section{B.3.1 Assets}

\section{- Equity:}

- Total return: [EQTR97\$]. Equity total return for the rest of the world. The country weights are constructed from Table 1 of The US Treasury's (2000) report on U.S. holdings of Foreign Long Term Securities. The country weights represent $75 \%$ of total foreign equity holdings by U.S. investors. For each country, a series for dollar quarterly total stock return is constructed. The local currency returns are converted into dollars using end of period nominal exchange rates against the dollar compiled from IFS after 1957 and from GFD before. Before 1987, total returns series for Mexico, Brazil and Switzerland (before 1966) are unavailable. The weights are adjusted appropriately. Table 5 reports the weights by subperiod and the total return series for each country.

- Capital gain: [EQR97\$]. The equity capital gain series uses the same country-weights as Table 5. For each country, a series for dollar quarterly capital gain return is constructed. Local capital gain returns from GFD are converted into dollars using end of period nominal exchange rates. Country-weights are reported in Table 6 .

\section{- Debt:}

- Total return: Weighted average of the total return on long term bonds and total return on short term bonds. Maturity composition: $75 \%$ long term, $25 \%$ short term, from Table 2 in the US Treasury's (2003) report on U.S. holdings of Foreign Securities.

* Long Term: [R\$@R]. Weighted average dollar holding period return on foreign long term bonds. The currency weights are taken from Table 11 of the US Treasury's (2000) report on 


\begin{tabular}{lccl}
\hline country & $1952-1954$ & $1954-2004$ & series \\
\hline UK & 24.44 & 23.61 & FT-Actuaries All-Share Index \\
Japan & 15.33 & 14.80 & Nikkei 225 Stock Average \\
France & 9.55 & 9.23 & SBF-250 Index \\
Netherlands & 12.02 & 11.61 & CBS All-Share Price Index \\
Germany & 7.30 & 7.05 & CDAX Composite Price Index \\
Canada & 7.95 & 7.68 & S\&P/TSX 300 Composite Index \\
Sweden & 4.36 & 4.21 & Affarsvarlden General Index. \\
Switzerland & 6.95 & 6.72 & Stock Indices-Composites - Switzerland Price Index. \\
Italy & 4.67 & 4.51 & Banca Commerciale Italiana General Index \\
Mexico & 3.93 & 3.79 & SE Indice de Precios y Cotizaciones (IPC) \\
Australia & 3.50 & 3.38 & ASX All-Ordinaries. \\
Brazil & 0.00 & 3.40 & Bolsa de Valores de Sao Paulo (Bovespa) \\
\hline
\end{tabular}

Table 6: Country-Weights, Equity Assets, Capital Gains.

\begin{tabular}{lcl}
\hline Currency & Weight (\%) & Source \\
\hline U.S. dollar & 59.67 & Yields on U.S. government 10-year constant maturity bonds (IFS) \\
Yen & 12.35 & 7-year Government Bond Yield (OECD) \\
Canadian dollar & 8.64 & Average yield to maturity on government bonds with life over ten years. (IFS) \\
German DMark & 9.05 & Yield on federal securities w/ residual maturities of over 9 to 10 years. (IFS) \\
UK pound & 5.35 & Gross redemption bond yield, at par with 20 year maturity (IFS) \\
French Franc & 4.94 & 10-year Government Bond Yield (GFD) \\
\hline
\end{tabular}

Table 7: Currency-Weights, Long Term Debt Assets.

U.S. holdings of Foreign Long Term Securities for the year 1994. Given the availability of country bond yield data, we cover about $80 \%$ of the long term debt positions. The currency weights are reported in Table 7 . Total quarterly holding period returns are calculated from the changes in yields (assuming that the yield equals the coupon and using the formula (10.1.19) in Campbell, Lo and MacKinlay (1997), p408) converted into U.S. dollars using end of period nominal exchange rates compiled from IFS after 1957 and GFD before.

* Short Term: [RSRW\$]. Weighted average dollar holding period return on foreign short term bonds. The currency weights are taken from Table 14 of the US Treasury's (2003) report on U.S. holdings of Foreign Securities for 2001. With the short term returns availability, we cover $99 \%$ of the short term debt positions. Short term local currency returns are converted into US dollars using end of period nominal exchange rates compiled from IFS after 1957 and GFD before. The currency weights are reported in Table 8:

- Capital Gains: [RN\$@RW]. Same weights are [R\$@RW] but using net returns instead of total returns, where net returns are constructed as $\ln (1+R N)=\ln (1+R)-\ln (1+Y)$ where $R N$ is the net return, $R$ is the total return and $Y$ is the yield. Local net returns converted into dollars using end of period exchange rates.

\begin{tabular}{lcl}
\hline Currency & Weight (\%) & Source \\
\hline U.S. dollar & 85.09 & Discount on new issues of 3 months Treasury Bill (IFS) \\
Dmark & 4.98 & Germany 3-month Treasury Bill Yield (GFD) \\
Yen & 8.01 & Lending rate for collateral and overnight loans in the Tokyo Call Money Market (IFS) \\
UK pound & 1.92 & Tender rate at which 91 days bills are alloted (IFS) \\
\hline
\end{tabular}

Table 8: Currency-Weights, Short Term Debt Assets. 
- Direct Investment: Returns constructed using rolling weights based on BEA's FDI historical cost positions, from 1966 to 2002. In each year, we cover $75 \%$ of US Direct Investment historical cost asset positions. Some countries are excluded for some years due to the absence of stock market data (e.g. Mexico, Brazil, Switzerland and Panama in early years). For each country, total stock return (in dollars) computed from GFD total return indices and IFS end of period exchange rates.

- Total return: [TRFDR $\$$ ].

- Capital gain: [RFDR\$].

- Other Assets:

- Total return: [RSRW\$]. See above

- Capital gain: none.

\section{B.3.2 Liabilities}

\section{- Equity and Direct Investment:}

- Total return: [EQTRUS]. Total Return Indices-Stocks - S\&P 500 Composite Total Return Index (Base 1988) (SPXTRQ).

- Capital gain: [EQRUS]: Stock Indices-Composites - S\&P 500 Composite (SPXQ)

\section{- Debt:}

- Total return: Weighted average of the total return on long term bonds and total return on short term bonds. Maturity composition: $75 \%$ long term, $25 \%$ short term, from Table 2 and Table 3 in the US Treasury's (2002) Survey of Foreign Portfolio Holdings of U.S. Securities.

* Long term: [R@C111]. Quarterly total return on long term bond. Calculated from the change in yields (see formula in Campbell et al. (1997), equation 10.1.19 pp408), assuming that the yield is equal to the coupon. Yields on U.S. government 10-year constant maturity bonds. Before 1985.3, yield data from McCulloch and Kwon (1993), as reported by Campbell (1999). After 1985:3, from IFS (L61@C111).

* Short term [R\$@C111]. After 1963:4, discount on new issues of 3 months Treasury Bill (IFS L60@C111). Before 63.4: Treasury bill rate in quarterly SBBI file in CRSP, from Campbell (1999).

- Capital gain: [RN@C111]. Quarterly net return on long term bond defined as $\ln (1+R N)=$ $\ln (1+R)-\ln (1+Y)$ where $R N$ is the net return, $R$ is the total return and $Y$ is the yield. The yield is already included in the current account transactions.

\section{- Other liability:}

- Total return: [R\$@111]. see above.

- Capital gain: none.

\section{B.3.3 Implicit Returns}

The implicit returns on each asset class are constructed as follows.

- For gross assets, we use the investment income series Table F107.7 and SCB NIPA table 9.5, line 5 (receipts of factor income), and our total valuation series for assets. We compute $r^{a}$ as (investment income+valuations)/ foreign asset position at the end of the previous period. 
- For gross liabilities, we use the investment income series Table F107.3 and SCB NIPA table 9.5, line 11 (payments of factor income), and our total valuation series for liabilities. We compute $r^{l}$ as (investment income+valuations)/ foreign liability position at the end of the previous period.

- A breakdown of the investment income at the level of each asset class is unfortunately not available over the entire period. Instead, we distributed investment income across each asset in the following way. First, we deducted from total investment income FDI-reinvested earnings. We distributed the remaining investment income across assets in proportion to their share in total assets. Thus we obtain estimates of investment income for equity, debt and 'other'. For FDI we add back reinvested earnings to the FDI investment income estimated as above i.e. we add reinvested earnings to (total investment income-reinvested earnings) multiplied by share of FDI in total assets. We then compute the implicit return on equity assets, say, in the following way: $r^{a e}=$ (investment income on equity+valuation change on equity)/equity asset position at the end of the previous period. We proceed in a parallel way for each asset class for gross assets and gross liabilities.

\section{Appendix C Miscellaneous Data Issues}

\section{C.1 Mapping the BEA returns for Direct Investment and the Treatment of Reinvested Earning.}

Denote $P X_{t}$ the stock at the end of period $t$ for series $X$ and $F X_{t}$ the flow for the same period. Assume that the returns are accrued at the beginning of the period, so that the accumulation equation from quarter $t$ to quarter $t+1$ takes the following form:

$$
P X_{t+1}=R_{t+1} P X_{t}+F X_{t+1}
$$

From the constructed series $P X_{t}$ amd $F X_{t}$ we can extract the implicit return:

$$
R_{t+1}=\frac{P X_{t+1}-F X_{t+1}}{P X_{t}}
$$

We then regress the continuously compounded annual returns $R_{t, t+4}=\ln \left(R_{t} R_{t+1} R_{t+2} R_{t+3}\right)$ on the annual return that is used to value the BEA series, $R_{t, t+4}^{B E A}$.

\section{C.2 How to treat discontinuities?}

The accumulation equation assumes that $N D_{t}$ represents capital gains. In some cases, the discontinuity is too big to be justified by capital gains. Instead, it represents a rebasing of the underlying series (e.g. Table F.107 line 26, U.S. corporate bond liabilities, or Table F.107 line 32, direct investment liability). The valuation equation is

$$
P X_{t+1}=P X_{t}+F X_{t+1}+D X_{t+1}
$$

$D X_{t}$ reflects both the capital gain and the discontinuity in year $t$. If there is a discontinuity at time $T$, we need to adjust both positions and flows before $T$. Our approach is to attribute all the adjustment at time $T$

to the discontinuity. Define the adjustment factor $\kappa=1+\frac{D X_{T}}{P X_{T-1}}$. We scale all positions, flows and previous discontinuities by $\kappa$ for $t<T$ :

$$
\begin{aligned}
P \hat{X}_{0} & =\kappa P X_{0} \\
F \hat{X}_{t} & =\kappa F X_{t}
\end{aligned}
$$

